\title{
A ASSOCIAÇÃO BRASILEIRA DE ENFERMAGEM E SUA CONTRIBUIÇÃO PARA O DESENVOLVIMENTO DE ENSINO DE ENFERMAGEM NO BRASIL
}

\author{
Anayde Corrêa de Cirvalho (1)
}

CARVAlHO, A.C. de - A Associação Brasileira de Enfermagem e sua contribuição para o desenvolvimento do ensino de enfermagem no Brasil. Rev. Esc. Enf. USP. 8(1):45-123, 1974.

$O$ estudo trata da contribuiçāo da Associaçāo Brasileira de Enfermagem ( $A B E n)$ no desenvolvimento do ensino de enfermagem no Brasil, pcla análise das resoluçôes tomadas em seus congressos anuais De monstrou que a Associaçāo sempre esteve atenta aos problemas ligados à formaçāo do pessoal de enfermagem e nesse sentido vem desempenhando o seu papel de entidade cientifico-cultural.

\section{INTRODUÇĀO}

Escrever sobre a contribuiçăo da Associação Brasileira de Enfermagem (ABEn) " no desenvolvimento da enfermagem em nosso País nāo constitui tarefa fácil, considerando-se o volume de suas realizaçōes; torna-se, porém, empreendimento fascinante quando a atenção se volta para a grande soma de resultados positivos, fruto de seus 46 anos de existência, todos eles traduzidos em dedicados esforços das enfermeiras " para o progresso de sua profissão.

(1) Professor Colaborador da disciplina Didática aplicada an Enfermagem. A ABEn, nome pelo qual será designada neste trabalho, passou por várias designacōes, como mostra o anexo 1. pég. I.

- Nestas duas primeiras fases, a ABEn era constitulda somente de elementos do sexo feminino. 
0 produto de todo esse esforço chega, todavia, ao conhecimento de um público bastante restrito dado o reduzido número de meios de difusão de que se vale $e$ as dificuldades que devem ser vencidas para garantir sua continuidade. São eles, a Revista Brasileira de Enfermagem (RBEn), seu órgão oficial de divulgação, de publicação bimestral, e o Boletim Informativo, mensal. A primeira, mais técnica do que informativa, traz material apreciável e de grande utilidade para um estudo sobre a evolução da enfermagem brasileira. Seus editoriais e artigos constituem fonte de consulta de inestimável valor. $O$ segundo $\varepsilon$ exclusivamente informativo, de tiragem limitada e conteúdo restrito, atualmente de quatro páginas e contem apenas noticias e informações que necessitam de divulgação mais urgente.

Outro obstáculo a ser ainda vencido é o da inexistência de literatura profissional em língua portuguesa, na proporção em que seria necessária. O Fundo de Impressão, criado pela ABEn, e que se destinaria à publicação de trabalhos produzidos pelas próprias profissionais de enfermagem, ou de obras traduzidas, selecionadas, parece não ter ainda alcançado a amplitude desejada; as enfermeiras, no entanto, sempre estiveram conscientes dessa lacuna, razão pela qual vêm se empenhando cada vez mais na publicação de suas experiências, que tem sido utilizadas como fonte de referência, tanto para os estudantes de enfermagem como para as próprias docentes, em seus estudos e pesquisas.

A consciência da necessidade de aumentar o número das fontes de consulta, aliada à preocupação de difundir entre os enfermeiros os resultados do zelo com que a ABEn procurou, em todos os anos de sua existência, servir a enfermagem e, como decorrência, os interesses nacionais no que se refere aos seus programas de saúde, levaram Marina de Andrade Resende, presidente da ABEn de 1958-62 e de 1962-64, a fazer as primeiras investigaçōes sobre fatos ocorridos no início das atividades da Associação; pcstcriormerte, a Liietoria eleita para os biênios 1954-65 e 1965-58 sob a presidência de Circe de Melo Ribeiro decidiu que fossem reunidos, em uma só publicação, todos os elementos que haviam contribuido para fazet a História da ABEn.

A primeira Comissão encarregada desse trabalho apresentou relatório em julho de 1968 quando da realização, em Recife, do XX Congresso Brasileiro de Enfermagem; alguns meses mais tarde a autora foi convidada para, tomando como base as primeiras investigações já realizadas, completar, 
dar nova forma e elaborar o relatório final de maneira a que o mesmo viesse a constituir o Histórico da Associação Brasileira de Enfermagem.

Um novo esquema foi feito, tendo sido verificado que em uma publicação desse tipo os detalhes devem ser omitidos mas que estes, pela importância que representam no ensino da problemática da enfermagem, poderiam vir a constituir um novo trabalho que servisse de subsidio às estudantes de enfermagem em seus estudos sobre o assunto.

O capítulo no qual são tratados os aspectos históricos da Associação Brașileira de Enfermagem 'que exerceram influência no desenvolvimento do ensino da enfermagem no Brasil, é objeto deste estudo; os acontecimentos que a eles se referem serâo apresentados em ordem cronológica, sempre que julgado mais conveniente e com as alteraçōes de forma que melhor se adaptem a este tipo de estudo.

Como primeiro passo para o desenvolvimento deste trabalho foi feita a seleção do material bibliográfico que poderia conter aspectos históricos relacionados com o problema em foco. Passou-se em seguida ao exame dos documentos oficiais da Associação, particularmente as atas de reuniōes e relatórios dos membros das diretorias e de comissōes permanentes e especiais.

Foi dada atenção especial aos documentários dos Congressos Brasileiros de Enfermagem efetivados anualmente, considerados como o fulcro de todas as suas realizaçőes. As recomendaçōes deles emanadas, resultado de discussões nas quais tomam parte enfermeiros de todas as regiōes do País, constituem fonte de inegável recurso histórico.

Dada a escassez de dados sobre os primeiros anos de existência da Associação foram gravajas entrevistas som membros de diretorias anteriores e enfermeiras diplomadas pela Escola de Enfermagem da Universidade Federal do Rio de Janeiro (EE Ana Neri) nos anos de 1925 e 1926. Por ter sido essa Escola - a pioneira do ensino de Enfermagem no Brasil - o berço da Associação, seus arquivos foram extensamente analisados. Para as primeiras enfermeiras formadas e com as quais não foi possivel manter contato direto foram enviadas cartas solicitando respostas a perguntas previamente elaboradas, referentes a esse primeiro período, ou pedindo um relato dos fatos então ocorridos e seus respectivos personagens. respectivos personagens. 
Vários trabalhos já foram escritos por enfermeiras considerando, de passagem, esse mesmo assunto. Visando a outros objetivos, os fatos históricos da Associação foram abordados por suas autoras de forma resumi$\mathrm{da}$, com a finalidade de apenas ilustrar a tese a ser defendida.

Entre outras, ALCÂNTARA 1 , DOURADO4 4 , PAIXĀO6, PINHEIRO7 e RESENDE11 descreveram, de modo panorâmico, os principais fatos indicativos da origem, evolução e dinamismo da Associação, como uma das fases da História da Enfermagem Brasileira.

Este estudo foi dividido em tres capítulos compreendendo as fases de maior ou menor atuação da $A B E n$ nos problemas do ensino de enfermagem. A primeira, que se caracteriza pela falta de fontes de informações, vai desde sua criação em 1926 até a data em que aparece a primeira documentação escrita, o livro de atas n! 2; a segunda fase abrange um periodo de certa inatividade, do qual resultou a segunda tentativa de dar novo alento à Associação *; a terceira e última pretende demonstrar a importância da realização dos congressos anuais na consecução de um de seus objetivos, como associação cultural: trabalhar pelo ensino e formação do pessoal de enfermagem.

Para maior facilidade de consulta as referências bibliográficas serão apresentadas no fim de cada capitulo, incluindo-se a parte referente à Introdução no Capítulo I.

\section{I}

FASE OBSCURA: AGOSTO DE 1926 A MAIO DE 1938

Pouco se sảe sobre a atliação da ABEn no período compreeiilido entre sua criação em agosto de 1926, até 1938, quando é iniciado o sežndo livro de atas das reuniōes administrativas.

Ofícios, cartas, relatórios e o primeiro livro de atas, documentos que deveriam fundamentar os fatos ocorridos nesses onze primeiros

- A primeira deu-se em 1929 quando a ABEn se filiou ao Conselho Internacional de Enfermagem. 
anos de sua existência, desapareceram no incêndio de sua sede prcvisória, no Rio de Janeiro, em 1951.

A revista Anais de Enfermagem, hoje Revista Brasileira de Enfermagem (RBEn), surgiu em 1932 quando foi publicado seu primeiro número em maio desse mesmo ano, embora tenha sido plano das enfermeiras editá-la logo após a criação da ABEn. Os seis longos anos de espera devem ter tido como uma das suas grandes causas o sempre presente fator econômico que, decorridos 40 anos desde sua primeira publicação ainda constitui problema para a Diretoria da ABEn. Os números correspondentes aos anos de 1932 a 1938, apesar de não conterem informaçōes objetivas e diretas sobre 0 assunto em pauta mostram, pelos artigos publicados, a preocupação constante da Associação com a melhoria do ensino e, em decorrência, da prática profissional; colaborar com a formação de profissionais capazes e eficientes já constituía um dos seus principais objetivos e a revista seria um dos meios auxiliares para alcançar esse objetivo.

Compreende-se que assim fosse e que o mesmo espírito continue a orientar, ainda hoje, suas principais realizaçoes.

Nascida do idealismo do primeiro grupo de diplomadas da EE Ana Neri, animadas pelo desejo de que os laços de amizade tão bera desenvolvidos durante os anos de estudo não fossem desfeitos pela necessária separação, e que os objetivos profissionais comuns as mantivessem unidas e fiéis aos seus ideais, a Associação sempre esteve ligada a uma Escola de Enfermagem, direta ou indiretamente. Das dez enfermeiras que ocuparam a presidência dessa agremiação, sete tinham sido ou eram docentes ou diretoras de Escolas de Enfermagem.

$\mathrm{Na}$ verificação dos fatos históricos desse primeiro periodo rem sempre é pussivel distinguir quardo as iriciativas e realizaçōes partiam da direção superior da Escola ou quando eram oriundas exclusivamente da Associação. A influência que a primeira exerceu sobre os atos e mesmo sobre a sobrevivência da segunda nesses primeiros anos é confirmada pelo testemunho das primeiras associadas e pelos artigos publicados em seu orgão oficial de divulgação.

Vale notar que a Associaçāo foi constituida, durante alguns anos, quase que exclusivamente por enfermeiras diplomadas por esea Forn 
la * única reconhecida como de padrões semelhantes aos estabelecidos por Florence Nightingale, em 1860, na Inglaterra e introduzido em nosso Pais, por enfermeiras dos Estados Unidos. PULLEN8, diretora da EE Ana Neri nos períodos de 1928 a 1931 e de 1934 a 1938, assim escrevia em 1934: Já devemos pensar no dia em que a Associação será composta de diplomadas de várias escolas. Quando tivermos atingido este ponto, nosso intercâmbio de idéias e experiências será muito mais rico e interessante. Por essa época a EE Ana Neri havia diplomado 142 enfermeiras 5 :.

Desde que a Associação foi criada, sua direção procurou sempre mostrar as vantagens de uma organização profissional e estimular as diplomadas para que pertencessem e participassem de seus trabalhos.

Vale notar ainda, com a evidência que com justiça se faz necessária, os esforços, a dedicação e o entusiasmo profissional do grupo de enfermeiras norte-americanas da Fundação Rockfeller que vieram implantar a enfermagem científica em nosso País e aqui permaneceram até setembro de 1931.

Convencidas de que uma profissão, segundo CLAYTON" para se desenvolver e progredir precisa contar com uma Associação e uma Revista souberam essas enfermeiras transmitir suas idéias e os benefícios de suas experiências e assim influenciar as primeiras enfermeiras brasileiras.

PULLEN 9 também afirmava, em outro artigo publicado nesse mesmo ano:

Todas as pessoas que estāo presentemente na profissão devem se compenetrar de que tem responsabilidade para com a Associafāo de Enfer meiras, como parte integrante que são de sua organizaçāo.

Não é por esforços inüividuais isoladcs, señäc pela sua concentraçāo que as profissões surgiram da mera necessidade para a concreta realiza-

- Tres das enfermeiras associadas haviam se diplomado no exterior: Edith de Maga Ihães Fraenkel - Adelina Zurob nos Estados Unidos \& Raquel Haddock Lobo, na Franca.

- De acordo com a revista Anais de Enfermagem de julho de 1934, p. 12, em 1934 havia 153 enfermeiras diplomadas pela EE Ana Neri.

- Lillian Cayton, Diretora da Escola de Enfermagem do Hospital Geral de Filadelfia. EUA, para onde foram enviadas as primeiras bolsistas enfermeiras da Fundaçäo Rockfeller. Nesso mesma Escola diplomou-se, em 1925 a primeira Diretora da EEUSP, Edith de Magalhães Fraenkel, cuja integral dedicaçăo à Entermagem nunca será convenientemente ressaltada. 
f̧ão atual da grande necessidade.

Por este motivo, se estamos empenhadas na conquista individual, devemos pessoalmente amparar tanto a organização nacional de enfermeiras como o serviço de enfermagem onde exercemos nossa atividade.

- E ainda PULLEN9 que, nesse mesmo artigo, procurando chamar a atenção para os problemas que deviam ser enfrentados pelas enfermeiras, traça um verdadeiro plano de trabalho quase todo voltado para o ensino, quando diz: Temos diante de nós o probleme de desenvolvimento da biblioteca para referéncias, a organizaçāo de institutos *de educaçāo, cursos de administração e instrução, manutenção do padräo da Escola e elevaçāo de outras escolas ao nosso padräo, organização da enfermagem estadual e uma multiplicidade de outros problemas a resolver... Tais problemas precisam da cabeça e do apoio de cada enfermeira diplomada e ha algum trabalho, por pequeno que seja, para cada uma de nós...; se recusamos nosso apoio, talvez estejamos atrasando ou impedindo o progresso de nossa profissĩo.

A convicção desta realidade, sempre presente entre as enfermeiras brasileiras, foi no passado $e t$ ainda hoje a força propulsora de todos os empreendimentos da ABEn e reflete no seu comportamento como organização. Os fatos comprovam a afirmativa.

O Decreto n? 20.109 de 15 de junho de $1931^{3 * *}$, que regulava o exercício da enfermagem no Brasil e fixava as condições para equiparação das escolas de enfermagem $e$ as instruções relativas ao processo de revalidação de diplomas, parece ter contado com a colaboração da ABEn na elaboração de seu ante-projeto.

Seu artigo 39 estabelecia que da banca examinadora para revalidação de diploma de enfermeiras diplomadas por escolas estrangeiras deviam fazer parte duas enformeiras diplomadas indicadas pela diretoria da Associaf̧āo de Enfermeiras Diplomadas Brasileiras

Ao fixar ainda os padrōes oficiais do ensino para fins de equiparação das escolas de enfermagem. à EE Ana Neri, demonstrava preocupação pelos problemas que poderiam surgir no ensino da enfermagem se náo fossem estabelecidas normas gerais para o seu desenvolvimento.

- Provavelmente referia-se a uma estrategia de ensino.

- Revogado pela Lei no 2.604/55. 
Essa preocupação por parte das enfermeiras existia já há algum tempo; diplomada a primeira turma em 1925, as enfermeiras nortoamericanas e brasileiras do Serviço de Enfermeiras do Departamento Nacional de Saúde Pública (DNSP) e da EE Ana Neri - perceberam desde logo que alguma medida que garantisse a eficiência na prática e no ensino da enfermagem deveria ser tomada e os fundamentos para a organização de outras escolas de enfermagem deveriam ser estabelecidos.

Com alguma surpresa, viram essas profissionais sua justificada aspiração tornar-se uma realidade: apresentado o projeto na primeira quinzema de junho de 1931, foi o mesmo promulgado no dia 15 do mesmo més e ano10.

Merecedora de destaque a atuação das enfermeiras norte-americanas que aqui ainda permaneciam, na elaboração do projeto do qual resul. tou esse decreto; baseadas em experiências anteriores tentaram evitar, por meio de uma legislação adequada, que sucedesse neste País o que consideravam falho no sistema de ensino de enfermagem nos Estados Unidos 2 ; naquele pais o número de escolas mantidas por hospitais aumentava na medida em que esses consideravam necessário o trabalho dos estudantes em estágio na existência de enfermagem aos seus doentes internados.

Vários acontecimentos podem ter estimulado as enfermeiras no trabalho para conseguirem a assinatura desse decreto:

1) o movimento feminista que lutava pelo voto da mulher, criado e liderado pela Dra Bertha Lutz ", Presidente da Federação Brasileira pelo Progresso Feminino, ao qual se alia a presidente da ABEn naquela época, Edith de Magalhães Fraenkel e, com ela, várias associadas;

2) o movimento sindicalista então iniciado;

3) a criação do Ministério da Educação e Saúde Pública pelo Decreto no 19.402 de 14 de novembro de 1930 que passou a responsabilizar-se por esses assuntos, antes da alçada do Ministério da Justiça e

- A EE Ana Neri era subordinada 80 Serviço de Enfermeiras do DNSP - Ministério da Justica e do Interior.

- Filha de Adolpho Luta, modico e cientista brasileiro que dirigiu o Instituto BacterioIbgico de S5o Paulo, atual Instituto Adolpho Lutz. 
Negócios Interiores;

4) maior atenção ao desenvolvimento do sistema educacional do País por parte do Governo, que vinha se esforçando para estabelecer padrôes uniformes de ensino entre as escolas.

De 1931 a 1938 nenhum outro documento foi encontrado que assinalasse o papel que a Associação vinha desempenhando em defesa dos interesses da comunidade $e$ de suas associadas pela manutenção de altos níveis de ensino e de prática da enfermagem.

As publicaçōes contidas em Anais de Enfermagem, quer em artigos científicos quer em notas sociais ou ainda nas páginas da seção Criticas Humoristicas, demonstram a convicçāo de suas associadas de que o valor e a utilidade da enfermagem somente seriam comprovados pela qualidade do trabalho apresentado, e esta depende do sistema de ensino of erecido e do controle do exercício da profissão.

Por este principio vem a $\mathrm{ABEn}$ hutando desde sua fundaçāo.

\section{REFERENCIAS BIBLIOGRÄFICAS}

1. ALCẢNCATARA, G. - Brief Review of Nursing in Brazil Rio de Janeiro, Ministério da Educação e Cultura, 1957.

2. - A enfermagem moderna como categoria profissional: obstáculos à sua expansão na sociedade brasileira. Tese apresentada à Escola de Enfermagem de Ribeirão Preto, 1962, p. 27.

3. BRASIL MINISTÉRIO DA SAUDE - Enfermagem (Leis, Decretos e Portarias). Rio de Janeiro, Serviço Especial de Saúde Pública, 1959, p. 56.

4. DOURADO, H. G. - Resenha histórice de Enfermagem no Brasil. Rio de Janeiro, Ministério da Educação e Saúde, 1950.

5. IMPERIAL, M.G.S.C. - Histórico da Associação de Ex-Alunas da Escola Ana Neri - Universidade Federal do Rio de Janeiro. Servir, Rio de Janeiro, Darrow Laboratórios S/A, (s.d.), p. 36.

6. PAIXÃO, W. - História da Enfermagem 4a ed. Rio de Janeiro, Buccini, 1969. 
7. PINHEIRO, M.R. - Nursing in Brazil. The International Nursing Bulletin, 6(2): 9, 1950.

8. PULLEN, - Bertha L. - Alguns objetivos das Associações Profissionais. Anais de Enfermagem, 2 (5) : 12, out. 1934.

9. - Aspectos da Enfermagem no Brasil. Anais de Enfermagem, 2 (4) : 13, jul., 1934.

10. - Historical Aspects of Nursing in Brazil. Mimeografia, fev. 1939, ps. 50 e 41.

11. RESENDE, M.A. - Historia. Revista Brasileira de Enfermagem, 16 (5): 337-378, out. 1963.

FASE ANTERIOR AOS CONGRESSOS BRASILEIROS DE ENFERMAGEM (CBEn) : MAIO DE 1938 A MARÇO DE 1947

Esse período assinala 0 início da história escrita da ABEn e tem como marco final a fase preparatória para a realização do primeiro Congresso Brasileiro de Enfermagem, em março de 1947.

No que se refere ao ensino, não foi pleno de conquistas e, como no período anterior, as aspiraçōes da Associaçāo nem sempre conseguiram a repercussão desejada. E de se notar, porém, a preocupação de suas lideres - em despertar nas enfermeiras o espirito associativo $\mathrm{c}$ a consciência da responsabilidade de sua participação na resolução dos prohlemas da classe.

A clientela a que a enfermagem servia, muito menos alertada sobre os seus direitos a asistência à saúde, de acordo com suas necessidades, nada reclamava e nada exigia. Essa conformidade, ainda existente em zossos dias e resultante do descobrimento da existência de profissionais melhor qualificados; pode ser una das causas do lento desenvolvimento quantitative da profissão, a lado da completa ignorância da juventude em geral sobre suas vantagens.

\footnotetext{
- Dentre outras, Edith M. Fraenkel, Maria Rosa S. Pinheiro, Glete de Alcàntara Haydé G. Dourado, ex-diretora, atual diretora, docente ex-docente da EEUSP respectivamente.
} 
Apesar de ter sido interrompida a publicação de seu órgão oficial de divulgação de 1941 a 1946 " , a ABEn passa, a partir de 1946, por transformaçőes que iriam repercutir positivamente, em futuro próximo, em suas atividades em prol de melhoria do ensino.

Com a modificação de seus Estatutos 1 foram criadas nesse mesmo ano as Divisões de Educaç̃̃o e a Divisão de Enfermagem de Saúde Pública * que tinham como finalidade manter em nivel superior o estudo dos diversos ramos da enfermagem ${ }^{2}$; da primeira, da qual era presidente Edith M. Fraenkel, deveriam fazer parte somente as enfermeiras pertencentes ao corpo docente das Escolas de Enfermagem e as Superintendentes de Serviços 3 .

A criação das suas duas primeiras seçz̃es estaduais nesse período, em São Paulo (1945) e na Guanabara (ex-Distrito Federal, em 1946), trouxe novo impulso à ABEn permitindo às enfermeiras de outros Estados uma participação mais direta na resolução dos problemas comuns (Anexo 1).

A manutenção da unidade de pensamento entre as profissionais sobre os padrōes uniformes de formação de novos elementos, exintente desde sua fundação em 1926, t um ponto importante que a ABEn sempre fez empenho em garantir e pelo qual sempre lutou.

\section{CONGRESSO PANAMERICANO DE ENFERMAGEM}

Realizado no Chile em 1942, contou com a presença de duas enfermeiras brasileiras que, como delegadas da ABEn, apresentaram um trabalho sobre a organização de escolas de enfermagem no Brasil 5 . Nesse documento, que reflete o pensamento da classe, após analisarem o sistema de ensino de enfermagem em vigor no Brasil, apontam diretrizes para as mudanças que se faziam necessárias a fim de atender as novas perspoctivas de saúde da população. Maior relevo na promoçăo da saúde e profilaxia da doença de-

\footnotetext{
- Reorganizeda em 1946 sob a orientaç0 e direcão de Edith M. Fraenkel, diretora de EEUSP de 1942 a 1956.

- Ambes je vinham funcionando, por deciséo da Diretoria, com oe nomes de Divietso do Enfermesem do Sectodo Pablica.
} 
veria ser dado durante todo o curso. Assim, os programas deveriam ser reformulados de maneira a: 1) melhorar o ensino das ciências básicas aumentando o número de horas de seus programas; 2) aprofundar os conhecimentos dos estudantes sobre a saúde mental para que estes pudessem aplić́-los no trato com os doentes e pessoas sadias; 3 ) preparar os estudantes para o ensino dos preceitos de saúde pública a doentes e sadios e das modemas aquisiçð̄es no campo da nutrição; 4) dar grande atenção ao ensino clínico individual ou em grupo; 5) oferecer ao estudante oportunidade de recreação, estabelecendo um limite de horas de trabalho; esse deveria ter tempo para aprender e também para ensinar os pacientes, durante a experiência de campo.

Salientaram as autoras a importância de uma reformulação no ensino como condição para que as escolas de enfermagem pudessem ser consideradas instituições educacionais "e não apenas fontes de recursos de pessoal para atender as necessidades do hospital.

\section{A ABEn E AS ESCOLAS DE ENFERMAGEM (EE)}

Embora muitas vezes de maneira indireta, a ABEn sempre exerceu influência na criação e desenvolvimento das escolas de enfermagem.

De acordo com o livro de leis sobre enfermagem, editado pela Fundação Serviço Especial de Saúde Pública em 19594, haviam sido criadas no Brasil, até dezembro de 1946, dezenove escolas de enfermagem. Desse número, oito (42\%) eram oficiais: Ana Neri, da Universidade Federal do Rio de Janeiro, GB; Alfredo Pinto, GB; da Universidade do Estado da Guanabara, GB, (ex-EE Rachel Haddock Lobo, da Prefeitura do Distrito Federal); da Universidade Federal Fluminense, RJ (ex-Escola Fluminense de Enfermagem); da Universidade de São Paulo, SP; da Universidade Federal de Minas Gerais (ex-Carlos Chagas); da Universidade Federal da'Bahia; e Magalhães Barata (ex-EE do Pará). As onze restantes (58\%) eram particulares: Luiza de Marillac, GB; da Cruz Vermelha Brasileira, GB; da Cruz Vermelha

- Pela Lei no 452 de 5 de julho de 1937, que organizou a Universidade do Brasil, a ER Ana Neri foi incorporada a esse Universidade como instituição complementar, 0 que já significava o reconhecimento de que o aspecto ensino deve ser diverso do aspecto exercício em uma escola de enfermagem.

O Decreto no 21.321 de 18 de junho de 1946 que aprovou o Estatuto da mesma Universidade colocou esta Escola como estabelecimento de ensino superior no mesmo nivel das demais que a constituiam. 
Brasileira, SP; Paulista de Enfermagem, SP, (ex-EE do Hospital São Paulo), Sāo Francisco de Assis, SP; Hugo W'erneck, MG; Hermantina Beraldo, MG; do Hospital São Vicente de Paulo, GO; Florence Nightingale, GO; Cruzeiro do Sul, GO; e Nossa Senhora das Graças, PE.

No que se refere à situação dessas escolas, seis já tinham sido equiparadas à escola padrão (Ana Neri) e as outras doze aguardavam equiparação, o que foi conseguido, para sete delas, entre os anos de 1946 e 1949 quando foi promulgada nova legislação sobre o ensino de enfermagem :

A ABEn sempre foi solicitada para indicar representante nas comissōes encarregadas da organização de uma nova escola de enfermagem.

Os assuntos relacionados com o ensino eram amplamente debatidos nas reuniões da Divisão de Educação, geralmente realizadas na Escola Ana Neri. Dessas reunióes, para as quais eram convocadas principatmente as Diretoras, saía a orientação que deveria nortear a programação do ensino nas diversas regiōes do País, e a atuação das enfermeiras, quando indicadas para missð̃es nessas mesmas escolas, tais como, a inspeçãa para fins de equiparaçäo6.

\section{INFLUENCIA DA ESCOLA DE ENFERMAGEM DA UNIVERSDADE DE SÃO PAULO (EEUSP) NO PROGRESSO DA ABEn}

A contribuição que esta Escola prestou à Associação, nesse periodo, pode ser considerada em razão da existência, em seu quadro asso ciativo, de figuras de grande valor e coragem, inteiramente voltada para 0 problema da formação de enfermeiras e que souberam, com seu conhecimento e experiência, transformá-la em uma das principais instituições de ensino de enfermagem do Pais.

A presidente da ABEn, Edith de Magalhães Fraenkel, que ocupara o cargo de Superintendente do Serviço de Enfermeiras do Departamento Nacional de Saúde Pública ", Ministério da Educação e Saúde, despe-

- A EE Alfredo Pinto (ex-Escola Profissional de Enfermeiros do Servico Naciona de Doenças Mentais) era isenta da equiparação - Decreto-Lei no 3.189/41.

- Desmembrado pela reforma do Departamento Nacional de Saúde (DNS) instituldo pelo Decreto no 1.040 de 11 de janeiro de 1939. Em 1941 o DNS foi reformado 
de-se de suas companheiras do Rio de Janeiro na reunião realizada em 17 de outubro de 1941, em vista de sua próxima partida para São Paulo onde vai dirigir, em comissão da Rockfeller, uma escola de enfermagem.

Assim foi e desta data até 1956 a EEUSP esteve sob a orientaç5o desta educadora de grande experiência em ensino e administração e que jamais deixou de contribuir com seu trabalho e entusiasmo para sua associação de classe.

Como presidente da ABEn permaneceu até setembro de 1943, passando mais tarde para a presidência da Divisão de Ensino de Enfermagem?

Uma vez estabelecida em São Paulo, continuou sua dedicação a ABEn, agora contando com a participação mais ativa de seu grupo de colaboradoras "nesta Escola e das próprias estudantes, futuras associadas.

Em março de 1946 reorganiza a revista Anais de Enfermagem, cuja publicagão estava interrompida desde 1941. Como redatora-chefe, transfere a. redecaio e a administração para a EEUSP e consegue, nesse primeiro ano de trabalho, a publicaço de quatro números da revista.

Em todos eles a colaboração cientifica desta Escola se sobressai; dezoito dos vinte e sete artigos publicados nesses quatro números foram de autoria de suas docentes $e$ alunas.

Em fins de 1946 o interesse geral da EEUSP é despertado para os preparativos do I Congresso Brasileiro de Enfermagem a ser realizado no ano seguinte em São Paulo, tendo a EEUSP como o centro das reuniōes administrativas e científicas.

A contribuição foi, pois, nos dois sentidos: da ABEn para a EEUSP e desta para aquela, mostrando, mais uma vez, a estreita relação existente entre a associação de classe e o ensino de enfermagem.

peto Decrotolei no 3.171/41, sondo criedas a Divisio de Organizacióo Senitária (DOS) - Diviseto de Organizecto Hospitalar (DOH). A Superintendincia Geral do Servico de Enfermegem foi discolvida por completo surgindo em seu lugar a Seçäo de Enformagem como dependencia da D.O.S. 
Safram desta Escola, cinco das dez presidentes eleitas para dirigir a ABEn ".

\section{REFERENCLAS BIBLIOGRÅFICAS}

1. ASSOCIAÇĀO BRASILEIRA DE ENFERMEIRAS DIPLOMADAS Anais de Enfermagem, 15(21(: 35, out.-dez., 1946...

2. - Estatutos, Rio de Janeiro, Verona, 1950, p. 6.

3. - Divisão do Ensino de Enfermagem e Divisão de Enfermagem de Saúde Pública. Anais de Enfermagem, 15(18): 37, jan.-mar., 1946.

4. BRASIL MINISTÉRIO DA SAŨdE - Enfermagem (Leis, Decretos e Portarias). Rio de Janeiro, Serviço Especial de Saúde Pública, 1959, anexo.

5. DOURADO, H.G. \& DOURADO, R.G. - Organização de Escolas de Enfermagem no Brasil. Anais de Enfermagem, 15(18): 21-25, jan.mar., 1946.

6. FRAENKEL, E.M. - Inspeção de Escolas de Enfermaggera. Anaie '̇e Enfermagem, 15(19): 6-8, abr.-jun., 1946.

III

CONTRIBUIÇĀO DOS CONGRESSOS BRASILEIROS DE ENFERMAGEM NO DESENVOLVIMENTO DO ENSINO DE ENFERMAGEM

\section{CURSO DE ENFERMAGEM}

De 1947 a 1972 a ABEn realizou vinte e quatro congressos nacionais ** Em 1953 organizou o X Congresso Internacional de Enfermagem

- Edith M. Fraenkel, Maria Rosa S. Pinheiro, Glete de Alcântara, Circe de Melo Ribeiro - Amalia Correa de Carvalho.

- Do I (1947) ao Vill (1955) foram denominados Congressos Nacionais de Enfermagem. Neste trabalho será utilizada para todos eles a designacão atual, Congreaso Brasileiro de Enfermagem. 
promovido pelo Conselho Internacional de Enfermeiras (ICN) e em 19610 II Latino Americano promovido pelo Committee Internacional Católico de Enfermeiras e Assistentes Médico-Sociais, ambos realizados no Rio de Janeiro.

O congraçamento das enfermeiras, a grande oportunidade de divulgação do progresso das ciências da saúde e das modernas tendências da enfermagem, a seriedade na discussão dos problemas a serem enfrentados e a oportunidade de conhecer outras regiöes do Pais *, fizeram sempre dos congressos uma das melhores fontes de desenvolvimento da enfermagem como profissāo e das enfermeiras individualmente.

Uma análise dos temas abordados, das resoluçð̋es e recomendações decorrentes de suas discussōes e que sempre serviram de orientação e rumo nas decisర̄es a serem tomadas mostram a grande influência que a ABEn vem exercendo no ensino de enfermagem em seus três níveis.

\section{CONGRESSO BRASILEIRO DE ENFERMAGEM (I CBEn)}

A idéia da realização do primeiro Congresso de Enfermagem partiu de Madre Marie Domineuc, docente da Escola Paulista de Enfermagem, lançada em uma das reuniōes da ABEn, Seçāo de São Paulo. Aceita a sugestão foi logo marcada a data e o local, de 17 a 22 de março de 1947 em São Paulo; as sessōes seriam realizadas no prédio da EEUSP, ainda não inaugurado 13 . Nessa mesma ocasião foi constituída a Comissão de Programa e as sub-comissões que deveriam auxiliá-la. A presidente da Seção de São Paulo, Edith de Magalhães Fraenkel, iniciou desde logo os preparativos para - conclave auxiliada, principalmente, por Ella Hasenjaeger, enfermeira norteamericana, consultora de enfermagem do Instituto de Assuntos Inter-Americanos atuando, na ocasião, como assessora junto à EEUSP.

Eleita presidente da Comissão de Programa, Ella Hasenjaeger não poupou esforços para que esse Congresso obtivesse o melhor êxito possivel, incentivando e orientando as enfermeiras brasileiras com a expe-

\footnotetext{
- A realizacão de um Congresso ó sempre motivo de crescimento; por esta razão cado ano escolhida, para sede do Congresso, a capital de um Estado que tenha condiçóes de hospodegem e cuja Segfo da ABEn se proponha a organizśllo.
} 
periência que trazia de congressos anteriores realizados em seu país.

0 objetivo do I CBEn foi elaborar, em conjunto, um programa eficiente de enfermagem, visando ao desenvolvimento da profissāo num plano elevado 7 .

A preocupação com o preparo das enfermeiras para as tarefas que realmente iriam desempenhar, com vistas à eficiência do seu trabalho nos hospitais, levou a Comissão de Programa a planejar estudos sobre alguns dos problemas existentes na época.

Administração, ensino e supervisão " - Considerando que as enfermeiras logo após o término do curso eram solicitadas para cargos de chefia, o preparo de enfermeiras-chefes foi assunto de muitos debates. Um programa para curso intensivo de emergência que deveria ser realizado no próprio local de trabalho foi apresentado por PINHEIRO29, com essa finalidade.

Alguns anos depois, em 1952, no VI CBEn, o assunto é novarmente abordado pela mesma autora 28 que, examinando as funçסes que as enfermeiras estavam exercendo e o preparo que recebiam, conclue com a recomendação às diretoras de EE para que incluíssem as disciplinas Pedagogia, Administração e Supervisão no currículo de suas escolas (R 2).

Apesar da convicção das educadoras de que as enfermeiras deveriam estar preparadas para o que realmente iriam fazer, a disciplina Administração somente foi inclurda no currículo das escolas de enfermagem em 1962, pelo Parecer no 271/62 do Conselho Federal de Educação19 (CFE) e a Didática, pelo Parecer 163/72"*, ambas aplicadas à Enfermagem. Algumas escolas, porém, já incluram noções dessas disciplinas em seus programas.

0 tema Administração constituiu parte do programa oficial do Congresso realizado em 1957; foi abordado ainda nos Congressos de 1952, $1957,1958,1959,1968$ e 1972 (R 2 a R 8).

- As recomendaçöes dos Congressos referentes a cada assunto encontram-se no fina de cada tópico e são assinaladas com a letra R, seguida do número correspondente a ordem em que a mesma se encontra.

- Conselho Federal de Educaçäo - Parecer 163/72. Fixa os mínimos de contecido duração do Curso de Graduação em Enfermagem e Obstetrícia. D.O. de 20/7/72 
Enfermagem Psiquiátrica - Disciplina inexistente até então nas demais escolas, vinha sendo ministrada na EEUSP graças aos esforços de sua consultora e de sua direção. A necessidade de melhorar a assistência de enfermagem nos hospitais psiquiátricos e a experiência que a primeira trazia dos Estados Unidos fizeram-na empenhar-se para que a Enfermagem Psiquiátrica fizesse parte do plano de estudos desta Escola, que foi a primeira a ministrá-la, tendo Ella Hasenjaeger como responsável tanto pelo ensino teórico como pela prática no campo. Pela mesma razão foi $O$ assunto inclurdo na programação deste I CBEn; posteriormente, o tema foi abordado apenas nos II, VIII e IX Congressos (R 1 a R 4), este último realizado em 1956.

À Divisão de Saúde Pública coube, nesse I CBEn, a discussão dos problemas que a enfermagem devia enfrentar neste setor e mostrar 0 que já vinha sendo feito em matéria de educação para a saúde nas regiões da Amazônia, São Paulo e Guanabara.

A formação do auxiliar de enfermagem também constituiu assunto considerado de muita relevância, tendo sido apresentados dois trabalhos nesse sentido. Como ainda não havia uma programação oficial para a formação dessa categoria de pessoal, as discussões visavam a preparar o terreno para a criação de cursos desse nível.

Da análise e discussão dos temas apresentados resultaram duas recomendações de interesse para o ensino: 1) que as escolas de enfermagem incluíssem em seus programas de Enfermagem Psiquiátrica um estágio prático de, no mínimo, dois meses de duração em hospital de doenças mentais; 2) que as escolas de enfermagem e hospitais interessados criassem cursos especializados, em nível universitário, para enfermeiras-chefes e supervisoras 15 .

A iniciativa da realização desse I CBEn demonstrou a confiança da classe em sua capacidade para resolver seus proprios problemas, por isso foi-lhe dada especial atenção. Na época a ABEn contava com apenas 200 enfermeiras em seu quadro associativo *

Os Congressos realizados nos anos seguintes não foram menos

- Dessas 200 sccias, 29 eram da Secão de São Paulo. No final do certame o número de socias dessa Seção elevou-se a 64 demonstrando que esse empreendimento e sempre fator de aglutinacia. 
profícuos; muito do que foi conseguido com respeito a atualização do currículo, ensino das disciplinas dos diversos ramos da enfermagem e preparo do campo de prática foi produto de recomendações desses Congressos.

\section{RECOMENDAÇÕES DOS CBE: SOBRE A INCLUSÃO DAS DISCIPLI- NAS ADMINISTRAÇAO, ENSINO, SUPERVISÃO E ENFERMAGEM PSIQUIÃTRICA NO CURRICULO DAS ESCOLAS}

\section{Administraçāo aplicada à Enfermagem}

R 1 - I CBEn (1947), n. 4 - Recomenda criação de cursos especializados, em nivel universitário, para enfermeiras-chefes e supervisores em EE e hospitais interessados.

R 2 - VI CBEn (1952), n? 7 - e) Recomenda às diretoras de EE: que promovam a revisão do currículo, procurando selecionar as atividades das estudantes e eliminar as repetições excessivas, a fim de tornar possível a inclusão no mesmo de Noções de Pedagogia, de Administração e de Supervisão, acompanhadas da prática correspondente.

R 3 - X CBEn (1957), n. 4 - Recomenda à ABEn que, por intermédio da Comissão de Éducação, faça um estudo dos cursos de administração atualmente em existência, sob o ponto de vista do conteúdo e duraçāo, a fim de poder planejar mais adequadamente para o futuro.

R 4 - no 11 - Recomenda às EE que seja dado aos estudantes desde os primeiros anos do curso, o ponto de vista de administração, em campo de estágio adequadamente preparado, sendo para isso aproveitadas as oportunidades e situações educativas que surgirem.

R 5 - XI CBEn (1958), n! 1 - a) Recomenda às EE que proporcionem ensino e prática em administração e supervisão durante o curso de enfermagem.

R 6 - XII CBEn (1959), n. 14 - Recomenda às diretoras de EE que sejam ministrados aos estudantes, no curso de formação, princípios de 
administraçāo aplicada à enfermagem, acompanhados de estágios de admi-

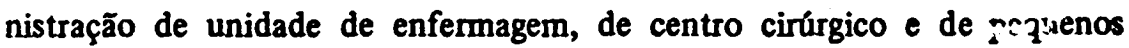
hospitais e que propiciem esses estágios em instituiçð̋es de condiçðes diversas.

R 7 - XX CBEn (1968), no 10 - Recomenda às EE que promovam a formação do aluno para as responsabilidades que the caberão no equacionamento dos problemas de liderança de sua profissão.

R 8 - XXIV CBEn (1972), n.0 2 - Às EE que nas disciplinas Administração aplicada à Enfermagem e Administração de serviços de enfermagem seja dada maior ênfase aos aspectos de supervisão e desenvolvimento do pessoal.

\section{Enfermagem Psiquiätrica}

R 1 - I CBEn (1947), n: 3 - Recomenda que as EE acrescentem ao ensino teórico da Enfermagem Psiquiátrica, estágio mínimo de dois meses, em hospital de doenças mentais.

R 2 - II CBEn (1948), no 10 - Recomenda reiterar às EE que acrescentem ao ensino teórico de Enfermagem Psiquiátrica, estágio mínimo de dois meses, em hospital de doenças mentais.

R 3 - VIII CBEn (1955), n. 18 - Recomenda às EE que no currículo do curso de enfermagem da primeira à última série sejam integrados os principios de higiene mental; e que seja incluído, obrigatoriamente, estágio de enfermagem psiquiátrica não inferior a oito semanas.

R 4 - IX CBEn (1956), no 17 - Recomenda às EE que proporcionem aos estudantes pelo inenos oito semanas de estágio de enfermagem psiquiátrica.

Nivel e duração do curso de graduaçäo

A partir da criação da Escola Ana Neri o currículo das escolas de enfermagem seguia o modelo norte-americano, tanto no conteúdo quanto na duração. Esta, que era de três anos de curso intensivo, com redução dos pe- 
ríodos de férias, foi alvo de muitos debates por parte das enfermeiras-educadoras. Embora a situação nacional exigisse, e ainda exija * a formação rápida desse profissional, é conviç̧ão de grande número de enfermeiras que esta mesma situação obriga as escolas de enfermagem a programarem seus currículos de modo a que o diploma somente seja concedido quando os alunos forem considerados convenientemente preparados para o desempenho das funções a que, na realidade, são chamados: administração, orientação e supervisão dos elementos da equipe de enfermagem, e educação sanitária dos pacientes. Para a maioria dos recém-diplomados, não há ainda possibilidade de afirmar-se profissionalmente pela ocupação hierarquisada de posiç̋̄es nas instituições que os empregam, comò seria desejável.

Em 1948, por ocasião do II CBEn, as enfermeiras foram alertadas sobre a necessidade dos cursos de enfermagem serem mantidos por instituiçōes de ensino e não por hospitais, ministrados preferentemente em nivel universitário em programas de três anos calendários de duração, o que equivalia a quatro anos acadêmicos. ( $R$ 2)

Evidenciava-se a preocupação de que o enfermeiro fosse preparado em instituiçōes cujo principal objetivo é o ensino e não o serviço, ambos de igual importância na formação do profissional e, por isso mesmo, de equilibrio difícil quando se trata de ampliar e aprofundar conhecimentos teóricos. Manter em nivel superior o ensino de enfermagem não somente daria melhores condições para um atendimento mais eficiente das tarefas que lhe cabem na resolução dos problemas de saúde da população como também criaria novos estímulos e atrativos para a profissão.

Com o desenvolvimento da enfermagem e a criação de outras escolas tornou-se evidente a necessidade de nova legislação sobre o ensino que, desde 1931, vinha obedecendo o disposto no Decreto $20.109 / 31$.

Em 1949 a Divisão de Educação da $\mathrm{ABEn} 9$ trabalhou ativa mente na elaboração de um currículo mínimo para escolas de enfermagem; desse trabalho resultaram a Lei no 775 de 6 de agosto de 1949 que dispunha

- Nos Gltimos trinta anos, de 1942 a 1971, diplomaram-se 9201 enfermeiros Na hipbtese de todos estarem em atividade e considerando a populaça atual do Pals. em cerca de noventa milhöes de habitantes, há um enfermeiro para cada 9.782 habitantes. A recomendaçäo da Organização Mundial de Saude para a América Latina e de 1:500. 
sobre o ensino de enfermagem no País e sua regulamentação pelo Decreto no 27.426 de 14 de novembro de 1949.

0 artigo 10 dessa lei criava o curso de auxiliar de enfermagem para a formação de outro tipo de profissional, a nivel pouco superiorao primário. $\mathbf{O}$ artigo 20 determinava a duração do curso de graduação em enfermagem em 36 meses $e$ o artigo 50 colocou o ensino de enfermagem em nivel superior pela exigência, para matrícula nesses cursos, de certificado de conclusão de curso secundário; entretanto estabelecia, em seu parágrafo único, o prazo de sete anos para que tal exigência fosse cumprida :

Não haviam passado ainda dois anos e já as enfermeiras, reunidas no V CBEn, em 1951, recomendavam à ABEn pleitear junto a Diretoria do Ensino Superior do MEC, que promovesse todos os meios ao seu alcance para fazer progredir o ensino de enfermagem do nivel de transição em que se encontrava para o de ensino superior, completando, desse modo, a obra iniciada com a Lei no 775 de 6 de agosto de 1949 (R 4).

Para melhor atendimento das necessidades de ensino, as diretoras das escolas de enfermagem foram convocadas, nessa mesma ocasiāo, a se reunirem numa comissão permanente integrada à Divisão de Educação, que deveria funcionar como órgão técnico de consulta, para dar pareceres à ABEn em assuntos tais como duração do curso de enfermagem e de auxiliar de enfermagem, seriação de disciplinas e estágios correspondentes ( $R$ 5).

Em 1953, a enfermagem brasileira teve consciència de que os problemas que vinha enfrentando não eram somentc setis, mas deles compartilhavam outros paises. De trabalhos apresentados no $\mathrm{X}$ Congresso Internacional de Enfermagem sobre as novas tendências no curriculo das escolas de enfermagem, algumas considerações feitas vinham de encontro às aspirações da $\mathrm{ABEn}$. Entre outras, que o cnsinc dc enfermagèn. a exemplo de outros programas de educaçāo, deve ser incorporado na estruturu élucacional do pais, ficando por ele responsável instituiçōes cuja junģüo frincipal seja a educacāo; e a tendência definida para um programa intcgrado de quatro anos $\varepsilon$ aparecimento de escolas de enfermagern de nivel unin'ersitário 34.

Essas duas aspirações das enfermairas já haviam aparecido

\footnotetext{
- Prazo prorrogado ate agosto de 1961 pela Lei no 2995 de 10 de dezernbio de 1956.
} 
como recomendação do VI CBEn em 1952 * e voltaram a ser feitas no VIII em 1955; neste último recomendava-se que a ABEn deveria empenhar-se, junto aos poderes competentes, no sentido de ser concedida às escolas de enfermagem já integrantes de universidades situação de igualdade com as demais unidades da instituição ( $R$ G).

Decorridos 23 anos após a promulgação da lei que colocou - curso de enfermagem em nivel superior podendo, portanto, integrar universidades (Lei 775/49), dezoito (55\%) das 33 escolas de enfermagem existentes em 1971 eram integrantes de universidades : E necessário reconhecer que essa situação foi devida, em grande parte, ao esforço individual de suas diretoras que souberam lutar em seus Estados para manter a Escola na posição que the cabe dentro da Universidade.

Em 1956 foi iniciado o estudo sobre a situação da enfermagem no País, cuja recomendação havia sido votada por ocasião do VII CBEn rez lizado em 1954 ( $R$ 7). Dessa recomendação resultou a instalação, naquele ano, do Centro de Levantamento de Recursos e Necessidades de Enfermagem no Brasil, cujo principal objetivo era obter dados concretos e exatos sobre o número de enfermeiros e de auxiliares de enfermagem em atividade $e$ as necessidades reais do $\mathrm{Pars}$, as funçōes que vinham exercendo, a qualidade do trabalho que vinham desempenhando, as funçōes que deveriam exercer, e os conhecimentos e práticas que seriam indispensáveis ao exercício dessas funçð̄es.

A parte $\mathrm{V}$ do relatorio final desse estudo, apresentado ao XI CBEn em outubro de 1958, foi inteiramente dedicada às escolas de enfermagem e apresentou informaçסes valiosas sobre a estrutura dessas escolas e as falhas que existiam no ensino.

Das recomendaçðes dele surgidas, algumas tem relação direta com o assunto relatado neste trabalho -:

\section{1 - Ao Conselho Nacional de Educação que exija, como}

\footnotetext{
- A resolução no 3 do VI CBEn referia-se a fato de que o ano letivo nas escolas superiores era de oito meses; por este motivo os très anos intensivos de enfermagem correspondiam, na realidade, a curso de quatro anos.

- ABEn - Relatório da Comissäo de Documentaç̄o e Estudos - 1971/72. No prelo.

- ABEn - Relatório do Centro de Levantamento de Recursos e Necessidades de Enfermagem, 1956 - 1958. Mimeografia.
} 
requisito indispensável para organizaçâo e funcionamento dos cursos de enfermagem ..., que a entidade mantenedora tenha objetivo educacional.

2 - As Universidades e aos Legisladores que dêm às escolas de enfermagem já existentes $e$ às que vierem a ser criadas condições para que adquiram status de estabelecimento de ensino superior.

3 - Às Instituiçōes mantenedoras de escolas de enfermagem ...

a) que tomem a si a responsabilidade de suprir os recursos necessários para a manutenção do ensino de enfermagem, no padrão recomendado pela Associação Brasileira de Enfermagem, inclusive que remunerem as professoras enfermeiras convenientemente, a fim de favorecer a sua permanência na escola em regime de dedicação exclusiva;

b) que instituam para as escolas, orçamento próprio, distinto do orçamento de outras obras pelas quais são responsáveis;

c) que gradualmente libertem as escolas da responsabilidade integral de suprir serviço de enfermagem aos hospitais de estágios.

4 - Às escolas de enfermagem:

a) que incluam no currículo de formação de enfermeiros: teoria e prática em administração de enfermagem, inclusive em pequenos hospitais particulares; teoria e prática em organização e administração de centro cirúrgico; estágio nas cinco áreas básicas da enfermagem: médicocirúrgica, obstétrica, pediátrica, psiquiátrica e de saúde pública;

b) que procurem suprir as insuficiências de seu campo de estágio por meio de filiação a outrás esculas, ou convênios corn instituiç̧̄es de saúde;

c) que tenham em seu corpo docente pelo menos cinco professoras enfermeiras de dedicação exclusiva ... para o ensino teóricoprático nas cinco áreas básicas de enfermagem;

d) que organizam cursos de pós-graduação em pedagogia e administração, visando o preparo de diretores e professores de cursos de 
enfermagem ... e de chefe de serviços...

5 - À Associação Brasileira de Enfermagem que... faça um estudo sobre os curriculos dos três niveis de curso, superior, médio e auxiliar, no qual sejam incluídos: cadeiras e disciplinas de cuitura geral e profissional com especial atenção às ciências sociais, sua correiação e seriação, a inclusão dos aspectos sanitários e sociais nas disciplinas, os estágios necessários para efeito de reconhecimento da escola e sua duração aproximada, e os requisitos mínimos dos campos de estágio.

Desde 1957 quando foi apresentado o projeto 3082/57 ; as enfermeiras vinham sentindo a necessidade de uma reforma no ensino de enfermagem; esse projeto que se tornou famoso por condensar em torno de si muitas idéias de enfermeiras educadoras sobre niveis de ensino de enfermagem foi arquivado em 196514.

O projeto da Lei de Diretrizes e Bases da Educação Nacional, que se transformou na Lei 4.024/61 - movimentou novamente a ABEn pela sua Comissão de Educação e sub comissão de Diretoras de Escolas de Enfermagem que desde 1959 vinham estudando os aspectos do ensino que poderiam interessar o futuro Conselho Federal de Educação (CFE) previsto no projeto como órgão controlador do ensino superior.

Em junho de 1962, uma Comissão de Peritos em Enfermagem -, nomeada pela Diretoria do Ensino Superior do MEC/DESu elaborou, a seu pedido, um projeto de currículo mínimo para ser apresentado ao CFE, como subsídio; esse projcto, preparado com base nos curriculos das várias escolas de enfermagem do País, previa curso de quatro anos de

- Previa o ensino de enfermagem em trés niveis, articulados lauxiliar, técnico e supe rior em dois, três e quatro anos respectivamente) e a diversificaçä́o do ensino nos dois últimos níveis após um tronco comuri de dois a trés anos, para a formação do enfermeiro e da obstetriz (nivel técnico) e da Licenciada em Enfermagem ou Licenciada em Enfermagem Obstétrica (nivel superior).

- Modificada pela Lei no 5.540/68.

- Criada em 1962, eram seus membros: Marina de Andrade Rezende, presidente da ABEn; Maria Rosa S. Pinheiro. Comissão de Educação, Maria Dolores Lins de Andrade; Haydée G. Dourado. Comissão de Legislação e Amalia Corréa de Carvalho, Comissão de Seguimento do Levantamento da ABEn.

Essa Comissão tinha como uma de suas principais atribuiçöes colaborar na formulaçăo de critérios adequados para a expansão do ensino superior lOfício no 4.793 da Diretoria do Ensino Superior do MEC à presidente da ABEn. Marina de Andrade Resende, em 5 de dezembro de 1962). 
duração e continha o que a classe considerava essencial no ensino, para a melhor assistência de enfermagem ao público5.

O CFE, com base no subsídio apresentado pela Comissão de Peritos e nas sugestరes das cscolas de enfermagem do País, elaborou e aprovou o Parecer no 271 em 19 de outubro de 1962; foi verificado, entretanto, que o subsídio apresentado pela $A B E n$ sofrera sérias modificações, tais como a exclusão das disciplinas Fundamentais da Enfermagem, Enfermagem de Saúde Pública e Ciências Sociais.

A exposiçāo de motivos apresentada pela ABEn solicitando a inclusão dessas disciplinas foi atendida somente no que se referia à primei$r a$, ficando as outras incluídas entre as matérias complementares, obrigatórias ou facultativas que poderiam ser acrescentadas ao curriculo mínimo; - Parecer 271/62 do CFE determinava a integração dos aspectos de Saúde Pública nas disciplinas de Enfermagem18.

Tal como foi homologado, o curriculo mínimo apresentava as seguintes modificaçбes em relação ao preparado pela Comissão de Peritos: curso de três anos de duração para formação do enfermeiro, exclusão das disciplinas Enfermagem de Saúde Pública e Ciências Sociais do curso geral; possibilidade de as escolas oferecerem um quarto ano, optativo, de graduação em Enfermagem de Saúde Pública ou Enfermagem Obstétrica, para preparar enfermeiras de saúde pública ou enfermeiras obstétricas.

No ano seguinte, 1963, é aprovado o Parecer no 303/63 do CFE que determinou o currículo mínimo do Curso de Enfermagem e de Obstetrícia "; modificando o Parecer 271/62; esses documentos mereceram a atenção da Comissão de Educação da $A B E n$ naquilo que afetava o ensino de Enfermagem.

İ̀m 1964 o XVI CBEn recomendava à ABEn que solicitasse ao CFE novo Parecer restaurando a duração de quatro anos para o curso de graduação de enfermagem ( $R$ 10). Essa mesma recomendação foi reitarada nos XVII e XIX CBEn em 1965 e 1967 respectivamente ( 11 e 12). A solicitagão feita pela ABEn em Memorial enviado ao CFE em 1964 não

- Homologada por Portaria no 513 do MEC a 23 de julho de 1964 e por Portaria no 251 de 17 de agosto de 1966, também do MEC; esta última incluia o currículo do Curso de Enfermegem. 
foi atendida. Em junho de 1965, porém, foi baixada a Portaria $159 / 65$ do MEC estabelecendo a duração dos cursos superiores em horas-aula com indicação dos limites mínimos e máximo de duração do cưrso20. Para a Enfermagem Geral o limite mínimo estabelecido foi de 2.430 horas; para Enfermagem de Saúde Pública ou Obstetrícia, 3.240 horas.

Parecer no 163/72 do Conselho Federal de Educaşäo e o atual curriculo minimo do curso de Enfermagem e Obstetricia

Com a reforma das estruturas universitárias iniciada em 1966 "e apressada pela homologação da Lei no 5.540/68, todos os currículos minimos deveriam sofrer uma reformulação por parte do CFE.

Em novembro de 1968 foi realizado na EEUSP um Seminario Nacional sobre Currículo do Curso de Graduação em Enfermagem, com a colaboração da Organização Pan-Americana de Saúde. Nesse Seminário, que contou com a participação ativa da $\mathrm{ABEn}$, foi apresentada uma proposta de currículo que procurava atender a Reforma Universitária e representava 0 consenso do grupo; este trabalho serviu de base para os estudos posteriores que resultaram na elaboração do anteprojeto preparado pela Comissāo de Educação da ABEn por ocasiāo do XXI CBEn realizado em 1969. Esse anteprojeto previa três ciclos para o pieparo ủo enfermeiro: I - ciclo pró profissional comum; II - ciclo profissional comum e III - ciclo profissional diversificado levando à formaçăo da Enfermeira Obstétrica e do Enfermeiro de Saúde Pública3.

Discutido no XXII CBEn em 1970, este recomenda que o anteprojeto seja enviado ao CFE como subsídio para a revisão do currículo mínimo do Curso de Graduação em Enfermagem6, o que foi feito em outubro c̉esse mesmo ano.

Da data do início do estudo em 1968, até jutho de 1970 (XXII CBEn), foram apresentadas, pela Comissão de Educação como subsídio ao CFE, quatro estudos acompanhados de exposição de motj vos4.

- Decreto-Lei nO 53/66 e Decreto-Lei nO 252/67. 
Em 28 de janeiro de 1972 o CFE aprovou o novo currículo mínimo do curso de graduação em enfermagem. Desta vez a ABEn e as Diretoras das Escolas de Enfermagem viram acatadas suas sugestoes sobre o ensino no que se refere à enfermagem: o currículo aprovado coincidia em quase todos os aspectos com o último estudo enviado pela $\mathrm{ABEn} e$ abria um campo maior de habilitação para a enfermeira.

A estrutura do currículo atual compreende três fases sucessivas: 1) a pré-profissional que inclui as matérias de 10 ciclo comum a todos os cursos na área das Ciências da Saúde; 2) tronco profissional comum que leva à formaçáo do enfermeiro; 3) fase diversificada :compreendendo as três áreas, Enfermagem Médico-Cirúrgica, Enfermagem de Saúde Pública e Enfermagem Obstétrica. $O$ novo currículo prevê ainda a licenciatura em enfermagem para quem pretende dedicar-se ao magistério de 10 e 20 graus.

Além dessas, as educadoras de enfermagem viram atendidas outras pretensóes pelas quais vinham lutando há dèz anos: a duração média de quatro anos para o curso de enfermagem geral e a inclusão das disciplinas Psicologia, Sociologia e Didática aplicada à Enfermagem.

Recomendações dos CBEn sobre o nivel e duração do curso de enfermagem

R 1 - Il CBEn, (1948), no 2 - Que o reconhecimento de Escolas de Enfermagem (EE) seja atribuição do Conselho Nacional de Educação como os demais cursos de nível superior.

R 2 no 3 - Que os cursos para formaçăo de enfermeiras sejam ministrados exclusivamente em EE (...), com duração nunca inferior a 3 anos e preferentemente de nível universitário.

R 3 - V CBEn (1951), no 2 - Que a ABEn deve pleitear junto ao Sr. Ministro de Educação e Saúde, aos membros do Congresso Nacional e às autoridades competentes nos Estados a criação de cátedras nas escolas governamentais, a serem ocupadas por enfermeiras ressaltando-se a obrigatoriedade do concurso para o seu preenchimento, na forma de lei. 
R 4 no 9 - Que a ABEn deve pleitear junto ao Diretor da Diretoria do Ensino Superior que promova todos os meios ao seu alcance pzra fazer progredir o ensino de enfermagem do nivel de transiçāo em que se encontra para o de ensino superior completando, desse modo, a obra que iniciou com a Lei no 775 de 6 de agosto de 1949.

R 5 no 11 - As diretoras de EE, c) que se constituam numa comissão permanente dentro da Divisão de Educaçāo para dar pareceres a Associação Brasileira de Enfermeiras Diplomadas (ABED) em todos os assuntos sobre os quais devam opinar, tais como duração do curso de enfermagem e enfermagem auxiliar; seriaçà de disciplinas inclusive de seus estágios respectivos.

R 6 - VI CBEn (1952), no 3 - Que a ABEn deve pleitear junto ao Sr. Ministro da Educação e Saúde que a duração do Curso de Enfermagem seja considerado de quatro anos (...).

R 7 - VII CBEn (1954), no. 14 - Que a ABEn deve estudar as necessidades de enfermagem do País e os níveis de formação profissional para fazer frente às necessidades.

R 8 no 16 - Que a ABEn deve empenharse junto aos poderes competentes, no sentido de ser concedida às EE Universitárias autonomia dentro das Universidades a que pertencem.

R 9 - XIV CBEn (1962), no 1 - A ABEn que: a) solicite ao Magnífico Reitor da Universidade do Paraná que se dirija ao Sr. Ministro da Educação e Cultura no sentido de conseguir que a EE da Universidade do Paraná a ser criada conforme Projeto de Lei no 3.257-C/57, ora em tramitação na Câmara dos Deputados, seja estabelecimento de ensino superior na Universidade e não escola anexa; b) solicite 203 Magnificos Reitores das Universidades da Paraŕba, Minas Gerais, São Paulo e Rio Grande do Sul que se empenhem para que as EE anexas sejam transformadas em estabelecimento de ensino superior.

R 10 - XVI CBEn (1964), n. 14 - Que a ABEn solicite do CFE novo Parecer restaurando o curso de graduação de enfermagem de quatro anos. 
R 11 - XVII CBEn (1965), n. 3 - Ao CFE que torne de quatro anos o curso de graduação de enfermagem no fim dos quais será conferido o diploma de enfermeiro graduado.

R 12 - XIX CBEn (1967) - Da Assembléia de Delegados à ABEn, para que solicite ao CFE, seja alterado o Parecer no 271/62 de modo que o 49 ano do curso de graduação em enfermagem seja obrigatório, possibilitando às escolas selecionarem as áreas a serem desenvolvidas no último ano, de acordo com as necessidades regionais ou locais (considerando a inconveniência de um curso de enfermagem ser desenvolvido em 3 anos e mais um ano optativo de Enfermagem Obstétrica ou Enfermagem de Saúde Pública, o que possibilita o enfermeiro entrar em exercício profissional ao fim de 3 anos, sem a formação necessária, justamente nas duas áreas de mais significado para as necessidades brasileiras).

R 13 - XX CBEn (1968), no 9 - Aos CFE, Conselho Estadual de Educação (CEE) e Reitores das Universidades que as EE, no contexto universitário, sejam organizadas como unidades autônomas de ensino superior e pesquisa aplicada.

Planejamento e organizaçāo dos curriculos do curso de graduação

Tão importantes quanto o nivel e duração do curso de enfermagem foram as discussōes sobre o conteúdo do currículo.

Partiu do IV CBEn, em 1950, a recomendação para que as escolas de enfermagem promovessem a correlação de todas as matérias do currículo ou a sua integração num todo harmônico; e que acentuassem o ponto de vista da Saúde em todas as matérias do curso ( $R$ 1).

Seguindo essa mesma ordem de pensamento várias outras recomendações foram feitas nos Congressos realizados em anos posteriores ( $R$ 3, 19, 25 e 26). A insistência das enfermeiras em discutir em conjunto o problema da organização do currículo bem mostra a importância que sempre foi dada ao assunto e o grau de influéncia da ABEn nas questōes do ensino. Pode-se mesmo afirmar que, praticamente, toda orientação nesse sentido partiu de resoluçōes tomadas nessas reuniōes. Das 617 recomendações feitas, 
258 (42\%) referem-se a assuntos relacionados com o ensino, computando-se como tal as que dizem respeito ao corpo discente e preparo do corpo docente. Noventa (35\%) dessas últimas foram destinadas ao planejamento dos curriculos.

Já em 1957 era pensamento das enfermeiraseducadoras que o currículo de uma escola deveria ser planejado com a participação de todos os que nele tomam parte para que os objetivos do ensino fossem bem definidos e houvesse maior integração entre a teoria e a prática; deveria incluir também, portanto, representante do corpo discente $e$ as chefes dos serviços de enfermagem das instituições utilizadas como campo de estágio ( $R$ 4b, 12, 16). Não há notícia de que:essa resolução tenha sido posta em prática nas $\mathrm{EE}$ antes da reforma universitária. Algumas escolas mantêm uma comissäo de ligação da qual fazem parte chefes dos serviços de enfermagem das institujções de saúde ligadas à Escola, e na qual são discutidos problemas de ensino surgidos nos campos de prática.

0 entrosamento ensino-serviço-ensino continua à ser, porém, uma das principais preocupações das enfermeiras; para a eficiência do ensino é necessário um relacionamento muito bem definido entre esses dois campos de atividades ( $R 2,17,20,21,22,28,29,42,43,52$ e 53).

Outro aspecto que mereceu a atenção do grupo de educadoras da ABEn foi o da utilização em grande escala, pelas escolas, do método ativo de ensino, recomendado desde 1952 como um dos meios de desenvolver nos estudantes o raciocínio rápido, julgamento e a capacidade de tomar decisōes, qualidades tão necessárias às suas futuras funçōes ( $R$ 4c, 9 e 35).

Quanto ao conteúdo do curriculo, além das disciplinas Administração, Supervisão e Ensino e Enfermagem Psiquiátrica, discutidas desde o I CBEn, em 1947, oụtras mereceram especial atenção da ABEn, porque consideradas indispensáveis à formação da enfermeira.

O aparecimento de recomendaçōes às EE para integrarem em seus currículos esse ou aquele conhecimento mostra preocupação em manter o ensino de enfermagem a paripassu com o desenvolvimento e tecessidades da sociedade. 
comunidade são referidas, via de regra, como dependentes do nivel educacional de um povo.

A enfermeira, pelo contato que tem com o público, está em condiçōes de prestar grande contribuição na melhoria dessas condições pelo ensino dos meios que devem ser empregados para evitar as doenças e restaurar a saúde; ao transmitir esses conhecimentos terá realizado grande parcela de sua função de educadora para a saúde e ao mesmo tempo terá assegurada sua participação na melhoria do nivel educacional do povo brasileiro. No VII Congresso Brasileiro de Higiene realizado em São Paulo em 1948 foi salientado 0 p̀apel vital que a enfermeira desempenha em qualquer programa onde se procura elevar o padrão de sauide de uma nação. 10

A ABEn consciente dessa realidade vem, desde 1950, recomendando as Escolas de Enfermagem que introduzam em seu currículo as disciplinas Enfermagem de Saúde Pública e Educação Sanitária e que, ao mesmo tempo, procurem integrar conhecimentos de saúde pública em todas as disciplinas do curso ( $R 1,2 b, 3,4,5$ e 12).

Sua preocupação com campos de prática que proporcionassem experiências valiosas para os estudantes resultou em várias recomendaçōes de Congressos nesse sentido, tanto às EE como às organizaçōes oficiais de saúde (R 2d, 7, 8, 9, 10).

0 currículo do curso de graduação, determinado pelo Decreto n. 27.426/49 (Regulamento da Lei no 775/49), incluía a disciplina Enfermagem de Saúde Pública e estágio em serviços urbanos e rurais de saúde pública.

Com a reformulação do ensino de enfermagem em 1962 (Parecer n! 271/62) o Conselho Federal de Educação excluiu essa disciplina do currículo mínimo, contra a opinião da Comissão de Peritos da ABEn e estat. . leceu um 49 ano optativo de Enfermagem de Saúde Pública mantendo, nc entanto, a obrigatoriedade de integração dos aspectos sanitários em todas as disciplinas do currifculo.

A partir de 1962 aparecem as recomendações da ABEn para que as Escolas que tivessem condiçōes oferecessem esse curso e que as demais incluissem efetivamente os aspectos preventivos em todo o curso de graduação (R 8, 11 e 12). 
Enfermagem Obstétrica - Essa disciplina sempre fez parte do currículo do curso de graduação, uma vez que a assistência integral à mãe e à criança é uma das funções da enfermeira.

Convencidas de que a assistência à gestante, à parturiente $e$ ao recém-nascido deve também ser integral e por isso não pode prescindir dos conhecimentos dos outros ramos da enfermagem, as enfermeiras educadoras sempre se esforçaram para oferecer, às enfermeiras, possibilidade de aprofundar conhecimentos em Enfermagem Obstétrica, após o curso geral de enfermagem, o que vem acontecendo desde 1944 ( $1,4,5,6,7)$.

O atual currículo mínimo (Parecer no 163/72) estabelece defnitivamente a formação da Enfermeira Obstétrica ou Obstetriz, como uma das habilitaçōes do curso de graduação em Enfermagem e Obstetrícia.

As disciplinas Enfermagem Pediatrica (R 1), Enfermagem em Tisiologia (R 2 e 3), Enfermagem em Doenças Transmissiveis e Hanseniase (R 4) foram alvo de sugestōes para revisão de programa ou inclusão no elenco das disciplinas do curso de graduação. Já em 1948 era evidenciada a necessidade de incluir Enfermagem em Tisiologia no currículo de enfermagem; a experiência no campo, porém, somente era possível nos serviços de saúde pública, uma vez que os hospitais especializados ainda não apresentzvam condições de segurança para os estudantes, porque não contavam com enfermeiras especializadas no assunto em seus quadros de pessoal 8 e das quais aqueles deveriam receber orientação no campo.

Psicologia e Ciências Sociais - Introduzidas oficialmente no currículo em 1949 (Lei 775/49), foram retiradas do currículo mínimo pela vigência do Parecer 271/62 e recolocadas pelo Parecer 163/72. As escolas, porém, nunca deixaram de inclur-las em seus programas de ensino.

A importância da integração dos aspectos sociais nas disciplinas do curso de graduação vem sendo posta em evidência pela ABEn desde 1948. Trabalhos apresentados no II CBEn, realizado nesse ano, mostraram a tendência em considerar $O$ aspecto social da enfermagem tão importante quanto o biológico na formação da enfermeira. Vários outros congressos trataram do assunto procurando sempre chamar a atenção das educadoras sobre o valor primordial do conhecimento do ser humano na prestação da assistència de enfermagem ( $R$ I a 4). 
Ética aplicada à Enfermagem - Embora a prática da ética profissional sempre estivesse intimamente ligada a qualquer situação de enfermagem, e a disciplina já constasse da Regulamentação da Lei 775/49, seu ensino somente mereceu a atenção da ABEn em 1952, no VI CBEn, quando foi sugerido à Comissão de Educação que elaborasse um programa de Etica que servisse de guia para as EE.

$O$ assunto foi tratado no IX CBEn, que o incluiu em seu temário oficial, e também no XIII CBEn (R 1 a R 4).

O código de Ética da ABEn, elaborado pela sua Comissão de Ética, foi aprovado pela Assembléia Geral realizada em 1958 por ocasião do XI CBEn. A disciplina, lecionada nos cursos dos três níveis de ensino de enfermagem, procura formar nos estudantes hábitos e atitudes baseados nos princípios do direito natural.

Saúde e Comunidade, disciplina obrigatória do atual currículo mínimo, foi recomendação do XX CBEn, em 1968 (R 2).

Além dessas disciplinas, as EE deveriam proporcionar aos estudantes conhecimentos de Relações Humanas (R 1), Com zaicação (R 3) e Geriatria ( $R$ 4), focalizados entre us demais, por constituirem problema muito em evidência na época atual.

Recomendaf̧ōes sobre o planejamento e organização dos curriculos do curso de graduação

R 1 - IV CBEn (1950), no 6 - Às EE que: a) promovam aa correlação de todas as matérias do currículo, integrando-as num todo harmónico; b) aceistuem o ponto de vista da saúde em todas as matérias do curso.

R 2 n? 7 - As instituiçōes oficiais e particulares utilizadas para estágios de estudantes, que desenvolvam seus serviços de enfermagem, incluindo equipamento necessário de modo a tornar esses estágios proveitosos.

R 3 - V CBEn (1951), no 12 - Às EE que encarem o ensino clínico inclusive nos seus aspectos de saúde, como o eixo da educação 
profissional da enfermeira e que esse ensino clínico se baseie em objetivos claramente definidos os quais servirão de critérios para seleção de experiências, organização e avaliação das mesmas.

R 4 - VI CBEn (1952) n.0 7 - Às diretoras de EE que: a) acompanhem com interesse $O$ movimento $e$ as tendências da educação geral, procurando enquadrar neles a enfermagem, a fim de que esta não se isole dentro de seus próprios padrões; b) dêm oportunidade ao corpo docente, a representantes do corpo discente e aos membros da coletividade interessados no ensino da enfermagem de tomarem parte no planejamento do curriculo; c) dêm oportunidade ao corpo discente para que tenha o maior número possível de experiências democráticas, com atenção especialmente à participação em atividades de grupo, a fim de desenvolver nas estudantes a capacidade de trabalhar em equipe; d) que procurem acompanhar a vida profissional de suas diplomadas como meio de avaliação da eficiência do currículo.

R 5 - VII CBEn (1954), no 15 - Que a ABEn designe uma Comissão para, em cooperação com a Diretoria do Ensino. Superior do MEC, traçar novas diretrizes para a elaboração dos programas de Concurso de Habilitação às EE e exame de admissão aos cursos de AE.

R 6 n.0 17 - Às diretoras de EE que (...): f) todos os estudantes sejam submetidos a testes psicologicos e que os resultados dos mesmos sejam utilizados nos programas de orientação educa. cional; g) os resultados das provas psicológicas sejam comparadas com o aproveitamento escolar e o ajustamento no curso, a fim de que essas provas venham contribuir para o estabelecimento de padrites que possam ser utilizados como critérios de seleção de candidatos.

R 7 - VIII CBEn (1955), no 16 - Às EE que (...) seja empregadio o método đe ensino ativo.

R 8 - IX CBEn (1956), no 6 - Às EE que façam seleção psicológica dos candidatos à Enfermagem, por meio do estudo de sua personalidade, de seu perfil psicológico obtidos por meio de testes e, quando necessário e possível, de entrevistas pessoais do candidato com um psícólogo.

R 9 n. 10 - Às EE que incluam em seu currículo o ensino clínico como complementaçāo indispensável à 
aulas de clínica e de enfermagem.

R 10 n. 13 - Às EE que as instrutoras e os professores clínicos participem do planejamento do currículo a fim de que sejam evitadas repetiçōes e lacunas nos programas.

R 11 n: 14 - Às EE que envidem esforços para melhorar o campo de estágio e que ao menos uma vez durante o curso proporcionem aos estudantes oportunidades de praticarem em um serviço onde a enfermagem seja quantitativa e qualitativamente boa.

R 12 no 15 - Às EE que orientem seus estudantes no tipo de trabalho de equipe fazendo-os funoionar sempre como membros da equipe de enfermagem.

R 13 n! 16 - Às EE que façam o ensino tendo a pessoa do paciente como centro de interesse.

R 14 - X CBEn (1957), no 10 - Às EE que no planejamento do currículo dos cursos de enfermagem e de auxiliar de enfermagem, haja participação do corpo docente, de representantes do corpo discente, dos chefes do serviço de enfermagem das instituições de saúde onde os alunos estagiam, de especialistas em educação e de representantes da famńlia do estudante.

R 15 - XI CBEn (1958), no 1 - b) que as diretoras de EE promovam reuniōes do corpo docente e das chefes de serviço de enfermagem a fim de estudarem os problemas encontrados pelas enfermeiras no desempenho de suas atividades e buscarem as soluções mais adequadas aos mesmos.

R 16 - XII CBEn (1959), no 13 - Às diretoras de EE $\in$ de Escola de Auxiliar de Enfermagem (EAE) que: a) façam seleção rigorosa de scus candidatos; b) durante o curso seja realizado um programa de orientação dos estudantes no sentido de aproveitar suas tendências inatas e de ajudá-los a encontrar solução para seus problemas pessoais e profissionais.

R 17 no 16 - Às diretoras de EE e de EAE que preparem enfermeiros cônscios de suas responsabilidades junto ao paciente, à famflia e à comunidade (considerando que as delimita- 
ções entre os campos de saúde pública e hospitalar vão deixando de existir à medida que se fortalecem os conceitos modernos sobre trabalho de comunidade, assistência hospitalar e educação de saúde).

\section{R 18 - XII CBEn (1959), n. 17 - Às diretoras de EE e de} EAE, que colaboram com os hospitais e unidades sanitárias onde os estudantes fazem estágios: 1) participando na supervisão dos serviços de enfermagem; 2) participando na organização de programas de educação em serviço; 3) procurando desenvolver nos estudantes interesse pelo ensino do pessoal do serviço e pela melhoria da assistência prestada ao paciente.

R 19 n. 18 - b) Às diretoras de EE e/ou de EAE, que se entrosem com a direção da instituição e do seu Serviço de Enfermagem, seja qual for a modalidade de suas relaçōes, a fim de: 1) promover reuniōes periódicas entre as equipes da escola e do serviço para planejamento das atividades dos estudantes e do pessoal de trabalho, discussão de problemas e avaliação dos resultados colhidos; 3) considerar situaç̋es em que a escola e a instituição poderão colaborar em trabalhos de pesquisas ou em emergências.

R 20 no 24 - Aos serviços hospitalares e sanitários que: a) procurem conhecer os objetivos e normas relativas a estágios das EE e de EAE; c) que sejam provider:ciados o equipamento e material indispensáveis para os estágios dos estudantes; d) que sejam proporcionados ambientes e meios para estudos e pesquisas; f) que orientem devidamente todo o pessoal no sentido de cada um colaborar para o bom aproveitamento dos estudantes, tanto no sentido técnico como no de formação de atitudes.

R $21-$ Recomendação da Assembléia Geral de 21/7/1959 - Que as EE, oportunamente procurem conhecer as condições mínimas para o estabelecimento de campos de estágio e façam esforços para melhorar, nesse particular, o ensino da enfermagem.

R 22 - XII CBEn (1960), no 10 - $\dot{A}$ ABEn que sugira às EE a reorganização do currículo, para obter melhor distribuição de matéria em cada série, considerando que na maioria das escolas há sobrecarga de matérias na $1^{a}$ série $o$ que prejudica a aprendizagem. 
R 23 n! 11 - Que a ABEn procure ajudar as Escolas na elaboração e execução de programas de integração dos aspectos sociais e de saúde no currículo.

R 24 n: 18 - Às EE e EAE que procurem proporcionar meios para a integração das disciplinas do seu currículo, considerando que qualquer forma de ensino favorecendo a integraçäo de disciplinas se sobrepōe em valores positivos ao de disciplinas isoladas.

R 25 - XIV CBEn (1962), n? 16 - Às EE que promovam a formação mais completa da enfermeira, estimulando e desenvolvendo as qualidades de lidera:ça e habilidades de trabalho em equipe.

R 28 - XV CBEn (1963), n? 1 - Às diretoras de EE e de serviços de saúde: a) que promovam maior entrosamento entre ensino $e$ serviço visando a melhor compreensão dos problemas de saúde e solução adequada.

R 29 no 2 - Às diretoras de EE: b) que estudem cuidadosamente os programas de trabalho dos serviços de saúde e orientem o preparo da enfermeira de saúde pública para a compreensão e execução dos mesmos.

R 30 - XVII CBEn (1965), no 9 - Às EE que: a) façam revisão dos seus currículos para inclusão de disciplinas de cultura geral; b) estimulem a iniciativa e a participação das estudantes nas várias atividades de cultura geral da própria Universidade e da comunidade.

R 31 - XVIII CBEn (1966), no 10 - À CAPES, DESu e Comissão de Educação da ABEn que: a) promovam um Seminário com a finalidade de orientar as enfermeiras dos três niveis de ensino de enfermagem, interessadas no método Instrução Programada, com especial atenção ao preparo do material; b) que constituam após o Seminário um grupo de trabalho para preparo de material julgado de maior interesse para os diferentes níveis de ensino de enfermagem; c) que realizem experiências piloto para aplicação do método referido com a finalidade de ampliar a sua aplicaรุāo. n! 10 d) - À Organização Pana - 
mericana de Saúde/Organização Mundial de Saúde (OPAS/OMS) que estude a possibilidade de auxiliar as instituiçōes acima referidas (dos três níveis de ensino de enfermagem) na realizzação do Seminário recomendado e das experiências piloto.

R 33 n: 11 - Às EE que procurem desenvolver nas estudantes segurança na elaboração do plano individual de cuidados de enfermagem aos pacientes que atenda às necessidades globais e que possa ser reformulado à medida que as necessidades do paciente se modificam.

R 34 n! 21 - À Comissão de Educação da ABEn que faça divulgação, através da ABEn, Grupos de Trabalho, Encontros e nas ocasiōes especiais quando essa comissão se reune, dos métodos modernos de ensino utilizados por algumas escolas.

R 35 - XIX CBEn (1967), no 1 - Às diretoras e corpo docente das EE que: a) na revisão do currículo dêm atenção à política global de educação, para reformulação dos objetivos dos estabelecimentos de ensino de enfermagem dos três níveis; b) os objetivos (dos cursos de enfermagem dos três níveis) sejam estabelecidos com base nos problemas prioritários nacionais e regionais de saúde; c) procurem adotar métodos atualizados de ensino que favoreçam o desenvolvimento do raciocínio, julgamento e adaptação dos futuros profissionais, para que possam exercer suas funçöes de liderança e agente social de desenvolvimento.

R 36 no 5 - Às enfermeiras docentes de cursos de graduação de Enfermagem que procurem introduzir o método de Instrução Programada, estudando-o através de reproduções e adaptaçס̄es de material existente.

R 37 n. 6 - Ao corpo docente das EE que adotem, contínua e sistematicamente, o plano individual de cuidados de enfermagem no ensino das disciplinas de enfermagem do curso de graduação.

R 38 no 7 - Às diretoras de EE que procurem introduzir nas escolas o estudo da Pastoral dos Enfermos, para dar aos estudantes maior possibilidade de atuação na assistência espiritual aos 
pacientes e na humanização dos ambientes de assistência à saúde.

R 39 n! 8 - Ao corpo docente das EE que procurem desenvolver nos estudantes valores capazes de encaminhálos para o trabalho de humanização dos ambientes de assistência à saúde.

R 40 - XX CBEn (1968), nọ 9 - a) À Comissão de Educação da ABEn que promova estudos permanentes sobre o estabelecimento de diretrizes gerais do ciclo básico, ouvidas as Comissões Estaduais.

R 41 n! 9 - b) As Seções Estaduais da ABEn, através da Comissão de Educação que instituam com urgência, Comissões Estaduais de especialistas, de representantes docentes e de instituiçōes relacionadas para estabelecer uma política educacional de enfermagem no contexto da Reforma Universitária; c) que realizem Seminários estaduais ou regionais para difundir a política educacional de Enfermagem.

R 42 - XX CBEn (1968), no 14 - Às diretoras de EE e de Serviços de Enfermagem, a) que instituam uma Comissão mista para estudo dos problemas referentes à integração, incluindo padronização e atualização de rotinas e de técnicas; b) que enfermeiros com preparo especializado participem do processo educativo dos estudantes; c) que promovam simposios, seminários e cursos entre corpo docente e enfermeiros hospitalares com objetivo de melhorar o relacionamento e atualização de conhecimentos; d) que sejam referendados os padrões mínimos para os serviços de enfermagem dos hospitais de ensino.

$$
\text { R } 43 \text { - }
$$
no 14 c) - Considerando que há necessidade de se estabelecerem critérios para avaliação do campo clínico, recomenda às diretoras de EE e de Serviços de Enfermagem: c) que promovam simpósios, seninários e cursos entre corpo docente e enfermeiros hospitalares com objetivo de melhorar o relacionamento e atualização de conhecimentos; d) que sejam referendados os padrões mínimos para os serviços de enfermagem dos hospitais de ensino.

$$
\text { R } 44 \text { - }
$$
n. 17 - À Comissão de Educação da ABEn que estude os critérios de articulação entre os vários niveis de ensino de enfermagem. 
R 45 n! 18 - Às Seçðes Estaduais que estudem o problema do currículo dos cursos de enfermagem e de auxiliares de enfermagem $e$ enviem sugestōes à Comissāo de Educação da ABEn

R 46 - XXII CBEn (1970), n! 1 - Às enfermeiras educadoras e de setores de serviço que conjuguem seus esforços no sentido de conceituas um modelo de enfermeira que sirva para orientar a formação da estudante.

R 47 n? 3 - Às EE que proporcionem aos estudantes experiências de aprendizagem em situaçōes diferentes; e que despertem nas docentes o interesse pelo ensino, através de análise e resolução de problemas de enfermagem.

R 48 no 4 - Às EE que procurem desenvolver nos alunos, desde o inicio do curso, interesse em assumir responsabilidade pela continuação de sua própria aprendizagem.

R 49 n! 6 - Às EE que se preocupem mais em desenvolver em seus alunos a capacidade de observação e análise, curiosidade intelẹctual e imaginação criadora, do que em thes dar informação.

$$
\text { R } 50 \text { - }
$$
n. 14 - $\dot{A}$ ABEn que envie ao CFE o anteprojeto do Currículo Mínimo do Curso de Graduação em Enfermagem, preparado por educadoras de enfermagem, como subsídio para a elaboração do currículo mínimo do Curso de Graduação em Enfermagem.

R 51 - XXIII CBEn (1971), n? 4 - Às enfermeiras educadoras e de setores de serviço, que a disciplina Fundamentos de Enfermagem inclua a técnica de observação sistematižda.

R 52 - XXIV CBEn (1972), no 3 - Às escolas e cursos de enfermagem, dos três níveis: b) que envidem esforços no sentido de conseguir melhor relacionamento entre docentes e enfermeiras das unidades das instituições utilizadas para a prática dos estudantes.

R 53 - XXIV CBEn (1972), no 9 a) - Às escolas e serviços de enfermagem que os campos de estágios sejam preparados adequadamente a fim de elevar o nivel de assistência de enfermagem, condição essencial para maior desenvolvimento do estudante. 


\section{Enfermagem de Saride Püblica}

R 1 - IV CBEn (1950), n.0 6 - Às EE que: c) acentuam o ponto de vista da saúde em todas as matérias do curso; e) que procurem obter a cooperação dos serviços de saúde do País, a fim de estabelecer conjuntamente um plano de atividades para o desenvolvimento de centros regionais que possam ser utilizados como campo de experiência das estudantes.

R 2 - V CBEn (1951), n! 12 - Às EE que: b) integrem os aspectos sociais e de saúde através de todo o currículo; d) que as EE que ainda não possuem campo adequado para o ensino térico prático da saúde pública procurem obtê-lo por meio de filiaçð̃es.

R 3 - VII CBEn (1955), no 17 - Às EE que não limitem o programa de enfermagem preventiva apenas a preleçðes $e$ a três meses de estágio em unidade sanitária, mas que procurem desenvolver no aluno um ideal positivo de saúde correlacionando os aspectos preventivos de todas as disciplinas do currículo.

R 4 - XI CBEn (1958), no 3 - Às EE: a) que o ensino de Enfermagem de Saúde Pública seja integrado em diferentes situaçōes de vida e de prática da enfermagem durante todo o perfodo de formaçāo; b) que as professoras de Enfermagem de Saúde Pública orientem as demais profes. soras da escola no sentido de que estas proporcionem aos estudantes oportunidades de integrar os aspectos sanitários e sociais em todo o currículo; c) que seja proporcionado às enfermeiras responsáveis pelo ensino de Enfermagem de Saúde Pública a oportunidade de frequentarem cursos de pós'graduação nessa especialidade.

R 5. - XII CBEn (1959), no. 20 - Às diretoras de EE que incluam no curriculo teoria e prática de Enfermagem de Saúde Pública.

R 6 - XIII CBEn (1960), n? 12 - Que a ABEn se encarregue da divulgaçāo (sobre as bolsas e cursos de especialização em Enfermagem de Saúde Pública), através da Comissão de Saúde Pública.

R 7 - $n$ n! 14 - Às Seçбes da ABEn que, pela Comissão de Saúde Pública, se entrosem com as organizaç⿸̃es 
oficiais de saúde, procurando interessá-las pela melhoria dos campos de prática nessa especialidade.

R 8 - XIV CBEn (1962), n! 17 - Às EE: a) dar aos alunos, além da integração dos aspectos sociais e de saúde nos diversos estágios, experiência de enfermagem de saúde pública em unidades sanitárias, ambulatórios e outros órgãos assistenciais; b) estabelecer convênio com organizaçð̃es de saúde para estágio dos alunos, quando houver conveniência.

R 9 no 18 - Às EE que procurem interessar as organizações da Previdência Social para oferecer oportunidades de estágios como complementação da experiência educativa em Saúde Páblica.

$$
\text { R } 10 \text { - }
$$
n. 19 - Às EE que procurem proporcionar, sempre que possivel, as estudantes, estágio de administração em Saúde Pública em pequenas comunidades rurais.

R 11 - XV CBEn (1963), n? 2 - Às EE: a) estudem cuidadosamente os programas de trabalho dos serviços de saúde e orientem o preparo da enfermeira de saúde pública para a compreensão e execução dos mesmos; b) que, em conjunto, estudem quais as que oferecem melhores condiçōes para desenvolver o 40 ano de Enfermagem de Saúde Pública e que, inicialmente, apenas essas Escolas assumam tal responsabilidade.

R 12 - XVII CBEn (1965), no 10 - Às EE que tornem efetiva a integração dos aspectos preventivos, sociais e de promoção da saúde em todo o curso de graduação, o que irá constituir motivação e base para o ensino de Enfermagem de Saúde Pública no 4: ano.

\section{Enfermagem Obstétrica}

R 1 - VI CBEn (1952), no 7 - Às diretoras de EE: h) que se interessem pela criação de curso de pós-graduação de Enfermagem Obstétrica; i) que promovam a revisão dos programas de Enfermagem Obstétrica do curso geral de Enfermagem com o fim de dar às estudantes oportunidades de fazerem partos visando prepará-las para atenderem a casos de emergências. 
R 2 no 8 - $\dot{A}$ redação de Anais de Enfermagem que contribuam mais substancialmente para a literatura profissional de Enfermagem Obstétrica.

R 3 - VII CBEn (1954), no 17 - Às diretoras de EE que: c) estimulem suas diplomadas a seguirem o curso de pós-graduação em Enfermagem Obstétrica, a fim de que possam, no futuro, estabelecer cursos de pós-graduação nessa especialidade.

R 4 - XV CBEn (1963), no 3 - Às EE que procurem realizar 040 ano de graduação de Enfermagem Obstétrica.

R 5 n. 7 e 8 - À ABEn: 7) que acentue junto à direção das EE a necessidade da realização do 40 ano de graduação de Enfermagem Obstétrica; 8) que envide esforços no sentido de obter recursos que possibilitem as enfermeiras interessadas, frequentarem os cursos de Enfermagem Obstétrica.

R 6 - XVI CBEn (1964), no 4 - À ABEn que continue responsabilizando as EE através da Comissão de Maternidade e Infância, no sentido de incrementar a abertura de cursos de graduação em Enfermagem Obstétrica, e que, para isso, promova a distribuição de bolsas de estudo, não só a professoras mas, a todas as enfermeiras que as necessitem.

R 7 - XIX CBEn (1967), no 9 - À Diretoria do Ensino Superior que no planejamento da formação de profissionais de enfermagem dê a ênfase que lhe parecer devida à formação de enfermeiras obstétricas e obstetrizes, para melhoria da assistência à maternidade e à criança.

R 8 - XXIV CBEn (1972), n! 13 - À Comissão de Educação da ABEn que promova estudos de grande amplitude, no sentido de investigar: a) a opinião de profissionais do sexo masculino, dos três níveis, sobre a utilidade do ensino teórico e prático de enfermagem obstétrica; b) o grau de aceitação ou rejeição das pacientes com relação ao atendimento por estudantes do sexo masculino. 
Enfermagem Pediatrica, em Tisiologia e em Doenças Transmissiveis

R 1 - VI CBEn (1952), no 7 - Às diretoras de EE: g) que promovam a revisão dos programas de Enfermagem Pediátrica do curso geral de Enfermagem, a fim de tornar a especialidade mais atraente para as futuras enfermeiras.

R 2 - VII CBEn (1954), no 17 - Às diretoras de EE: b) que na organização do currículo, dêm a devida importância ao ensino e às experiências de Enfermagem em Tisiologia.

R 3 - XI CBEn (1958), no 9 - À ABEn que solicite à Campanha Nacional Contra a Tuberculose a preparação de campo adequado para estágio de estudantes de enfermagem.

R 4 - XIX CBEn (1967), no 13 - Às diretoras de EE que propiciem aos estudantes conhecimentos atualizados sobre doenças transmissiveis em geral, especialmente lepra e tuberculose, com base nos trabalhos e normas técnicas da CNCT "e CNCL ", de modo a torná-los capazes de dar contribuiçōes positivas no controle dessas doenças, principalmente nas regiōes de maior endemicidade.

Psicologia e Ciências Sociais

R 1 - V CBEn (1951), n? 12 - Às diretoras de EE que integrem os aspectos sociais e de saúde em todo o currículo.

R 2 - VIll CBEn (1955), n! 8 - Às EE que, na organização do curriculo do curso de enfermagem, seja dada maior amplitude 30 ensino de ciências sociais ...

R 3 - IX CBEn (1956), no 18 - Às EE que façam uma revisão de programas de psicologia, ampliando-os se necessário (considerando a importância dos estudantes trazerem para estágios de enfermagem psiquiátrica uma base sólida de psicologia).

- Campanha Nacional contra a Tuberculosa.

- Campanha Nacional contra Lepra. 
R 4 - XVII CBEn (1964), n! 7 - Às EE que dêm ênfase, em seus currículos, aos estudos das ciências humanas, especialmente Psicologia e Ciências Sociais.

Etica em Enfermagem (Deontologia Médica)

R 1 - VI CBEn (1952), n! 5 - À Divisão de Educação da ABEn que elabore um programa de Ética destinado a servir de guia para as escolas de enfermagem.

R 2 - IX CBEn (1956), no 9 - Às EE que incluam no seu curriculo um curso de Etica baseado em princípios filosoficos e que facilitem a integração dos princípios de Ética nos acontecimentos cotidianos.

R 3 - XIII CBEn (1960), no 4 - $A$ ABEn que promova cursos de Ética através de suas Seçðes Estaduais, visando o aperfeiçoamento dos enfermeiros que ministram essa disciplina.

R 4. no 15 - Às EE que: a) façam uma revisão de seus programas de Ética dando-lhes melhor organização, ministrando-os em todas as séries do curso e ampliando-os com os princípios fundamentais da Ética básica; b) obtenham a participação de todos os membros do corpo docente, no trabalho de revisão do currículo, visando integrar o ensino de Ética em todas as disciplinas do currículo; c) proporcionem um ambiente são, condizente com o desenvolvimento moral do estudante, que não aprende Ética somente em salas de aula, mas, sobretudo, pelo exemplo dado pelos professores e pelos que trabalham nos serviços de saúde utilizados como campos de prática; d) incentivem os launos a estudar cuidadosamente os códigos de ética para ser compreendida a necessidade de sua observância pelo enfermeirơ; e) enriqueçàm suas bibliotecas com obras sobre Ética Básica e Aplicada proporcionando assim meios para o desenvolvimento desse assunto; f) não restrinjam apenas ao professor encarregado do currículo a responsabilidade de avaliação do ensino de Ética, ao contrário, estendam-na a todo o corpo docente da Escola, aos componentes do Serviço de Enfermagem nos campos de estágio, aos que mantem contatos profissionais com os estudantes e aos empregadores, através de um programa de seguimento dos diplomados; g) que continuem mantendo intercâmbio com a Comissão de Etica, informando-a sobre os resultados da execução das reco- 
mendaçð̃es acima e sobre novas referências bibliográficas.

Saúde e Comunidade, Relaçōes Humanas, Comunicașão e Geriatria

R 1 - XII CBEn (1959), no 15 - Às diretoras de EE que incluam no seu currículo Relações Humanas como disciplina independente.

R 2 - XX CBEn (1968), n! 7 - Às EE: b) que seja oferecido curso regular sobre Saúde e Comunidade aos estudantes do curso de graduação, quando se ressaltará a importância da Enfermagem na Equipe de Saúde.

R 3 - XXI CBEn (1969), no 8 - Às EE que integrem, em todo o currículo do curso de graduação, aspectos da teoria da Comunica'ção e propiciem ao educando oportunidade de desenvolver habilidade nas formas de comunicação, nas diversas situações de ensino e aprendizagem.

R 4 - XXIV CBEn (1972), no 5 - Às escolas e cursos dos três niveis de ensino de enfermagem que sejam incluídas no curriculo dos cursos, experiências educativas em Geriatria.

\section{CURSO TÉCNICO DE ENFERMAGEM}

Data de 1950 a primeira tentativa de introdução de nova modalidade de curso no sistema de ensino de enfermagem, além dos previstos na Lei 775/49 (curso de enfermagem e curso de auxiliar de enfeirnagem).

Em trabaiho apresentado no IV CBEn, 1950, DOURADO25, ao tecer consideraçōes sobre a necessidade da enfermagem buscar novas förmulas de preparo de pessoal a fim de atender à diversificação de suas funções, recomendou à ABEn estudos no sentido de ser criado o que denominou de curso básicò de auxiliar de enférmagem, de quatro séries anuais de duraçāo, num total de 32 meses letivos; a exigência de um ano prévio em que seriam ministradas as disciplinas de cultura geral, comuns aos cursos secundarios de 20 ciclo, possibilitaria a articulação com o curso de enfermagem, the posição já firmada no nível superior de ensino. 
0 curso de auxiliar de enfermagem, tal como estabelecido em lei, deveria ficar definitivamente na faixa correspondente ao 10 ciclo de grau médio e colocado na esfera do ensino vocacional ou de adultos (atual ensino sepletivo).

Este plano de reforma na lei do ensino de enfermagem não teve repercussão imediata na $A B E n$. A recomendação no $5 c$ do IV CBEn refere-se apenas à necessidade de a $\mathrm{ABEn}$ estudar, com a maior brevidade ... os elementos que servirāo de base à remodelação da Lei 775 e, consequentemente, do seu Regulamento, no sentido de atender, da melhor forma, os objetivos do curso de auxiliar de enfermagem 16.

Em 1956 deveria terminar o prazo de sete anos dado às escolas pela Lei $775 / 49$ durante os quais estas podiam receber candidatos com apenas certificado do curso ginasial.

Esse fato, segundo algumas educadoras, acarretaria diminuição do número de candidatos às escolas, o que não era conveniente. As enfermeiras reunidas no VIII CBEn, realizado em 1955, prevendo esta possibilidade, recomendaram à $A B E n$ um estudo sobre a conveniência da criação em lei de outro nível de curso de enfermagem ( $R$ 1) a fim de possibilitar $O$ aproveitamento de candidatos com apenas aquele nível de escolaridade. A Comissão de Educação, em estudo realizado em 1955 sobre os candidatos aos cursos de enfermagem, chegou a conclusão de que a maior porcentagem destes ainda era constituída de elementos que tinham concluido apenaso 10 ciclo do curso secundário : Nesse mesmo ano a Comissão reune as diretoras de escolas para estudarem o assunto e por decisão unânime, à revelia do corpo docente de algumas escolas, é aceita a proposta de prorrogação, por mais cinco anos, da exigência de secundário completo como requisito mínimo para matrícula àqueles cursos ", mas permitindo às escolas que tivessem condiçð̋es, a matrícula dos dois tipos de candidatos, em turmas separadas: portadores de certificado de curso clássico, científico ou equivalente (nível superior) e de portadores de certificado de curso ginasial ou equivalente (nível médio). Uma vez decidido o assunto, que vinha há muito dividindo as enfermeiras em suas opiniōes, foi elaborado um substitutivo ao projeto $2.991 / 51$ que adiava aquela exigência por mais sete anos 30 .

- Relatório da Divisão de Educação da ABEn, 1955. Documento da Escola de Enfermagem da Universidade do Rio de Janeiro. Ana Neri.

- Livro de Ates no 3. Reunião da Diretoria realizada em janeiro de 1956. 
A própria lei 775/49 ao estabelecer apenas os cursos de nível superior e elementar de enfermagem deixava em aberto a possibilidade da criação de outro nível de ensino de enfermagem.

Obtida a prorrogação do prazo com a promulgação da Lei no 2.955 de 10 de dezembro de 1956 a EEUSP, como uma das poucas em condições de o fazer, planejou em 1958 o inf́cio do funcionamento de cursos nos dois níveis de ensino, superior e médio, cursos esses que funcionaram até 1963 quando se diplomou a última turma de nível médio.

Esta foi a primeira tentativa que se conhece de estabelecer cursos para a formação desse novo grupo de profissionais de enfermagem; não deu os resultados esperados por não ter amparo legal e os seus diplomados puderam registrar seus diplomas como enfermeiros da mesma maneira que os demais.

Em 1957 a comissão "encarregada de elaborar o anteprojeto de Lei Orgânica do Ensino de Enfermagem , assessorada por enfermeiraseducadoras da $\mathrm{ABEn}$, apresentou relatório no qual era prevista também a formação de técnicos de enfermagem em cursos de nível médio de três anos de duração, além dos cursos superior e de auxiliar de enfermagem. Esperava-se com esta medida maior afluxo de candidatos à profissāo24.

Com a reabertura da discussão do projeto de Lei de Diretrizes e Bases da Educação Nacional (LDB) -"em 1959, pela Câmara dos Deputatados 2 , a ABEn procurou manter-se alertada, pelas suas Comissöes de Educação e Legislação, para que não houvesse conflito entre o projeto de reforma do ensino de enfermagem e o referido projeto de lei que previa, na faixa do 20 ciclo de ensino, a formação de técnicos de nível médio.

As discussōes na ABEn sobre a conveniência ou não de mais uma categoria profissionai na enfermagem, aparentemente sem funçס̄es a desempenhar na equipe de enfermagem, duraram de 1957 a 1968 e as

- Designada pelo Ministério da Educacão e Cultura em 1956.

- Projeto 3.082/57, arquivado em 1964 por estar em desacordo com a Lei de Diretrizes - Bases da Educaçá Nacional (LDB).

- Este projeto havia sido elaborado ha dez anos por uma Comisato constitulda pelo Ministro Clemente Mariani, da pasta da Educaçjo - Cultura - presidida pelo Prof. Lourenco Filho. Foi trensformado na Lei n? 4.024 de 20 de dezembro de 1961 (LDB), modificada pela Loi n? $5.540 / 68$. 
opinið̌es sempre divergiram. A Assembléia Geral Extraordinária realizada em 1961 foi contra o curso técnico de enfermagem. Os Congressos realizados nos anos de 1955 (VIII CBEn), 1965 (XVII CBEn) e 1967 (XIX CBEn) fizeram à $\mathrm{ABEn}$ recomendaçð̄es favoráveis à organização de cursos colegiais de enfermagem, mas em 1968 (XX CBEn) a posição dominante dos enfermejros que dele participaram foi contra a existência dos mesmos, embora já estivessem em funcionamento desde 1966 ( $R$ 1 a 5). Nesse ano sairam disposiçōes legais nos Estados da Guanabara e Pernambuco determinando as condiçðes de funcionamento dos Cursos Técnicos de Enfermagem, que continham elementos com os quais a $\mathrm{ABEn}$ não concordava. Diante disso as EE Ana Neri e Luiza de Marillac, da Guanabara, solicitaram ao CFE a criação de cursos desse nível nas respectivas Escolas o que deu origem aos Pareceres nos. 171/66 e 224/66 das Câmaras de Ensino Primário e Médio (CEPM), já agora de acordo com o pensamento da ABEn.

Naquele ano, 1966, foram criados quatro cursos colegiais de enfermagem, de três anos de duração para a formação de técnicos de enfermagem: dois na Guanabara, um em Goiás e um no Paraná; desses, três estavam sob a responsabilidade de escola de enfermagem e um era ligado a uma escola de auxiliar de enfermagem. As diretoras dessas escolas eram de parecer que a política educacional do Governo, expressa na LDB, não deixava dúvidas quanto à necessidade de formar profissionais de nível médio em grande escala para atender as mais urgentes necessidades do País.

Uma vez criados os cursos, tratou a ABEn de procurar integrálos, também definitivamente, no sistema de ensino de enfermagem, orientando suas Seções Estaduais para que continuassem apresentando subsidio aos CEE sobre o currículo desses cursos. Uma de suas primeiras tarefas foi a tentativa de definição de funçōes feita por DOURADO, em 196626. Nesse mesmo ano, as Comissōes de Educação e de Documentação e Estudos da ABEn planejaram, coordenaram as atividades e assessoraram os debates do Primeiro Seminário Regional de Ensino Médio de Enfermagem - Regiāo Sul, realizado em Curitiba, PR, com a cooperação de membros da Secretaria de Educação do Paraná, Escola Técnica de Enfermagem Catarina Labouré, EAE Caetano Munhoz da Rocha, EE Madre Leonie e ABEn - Seção do Parană. Esse seminário foi organizado para discutir o planejamento dos currículos dos cursos desse nivel. Dele participaram, como convidadas, uma representante de cada uma das Escolas Técnicas e Escolas ou Cursos de Auxiliar de 
Enfermagem da Regiāo Sul. Seu relatório final constitui ainda hoje o unico documento existente sobre $o$ assunto e apresenta um quadro comparativo das funçðes de cada uma das categorias de profissionais de enfermagem (superior e médio de 10 e 20 ciclos) que tem sido grandemente utilizado como material de consulta.

Apesar do aumento verificado no número de escolas ou cursos técnicos de enfermagem, passando de quatro em 1966 para $17 \mathrm{em}$ 1971, as funçőes que essa nova categoria deverá desempenhar ainda não foram regulamentadas, embora a solicitação tenha sido feita pela ABEn, aos órgãos competentes, em 1970. 0 projeto de lei n: 2.234/70 que acrescenta dispositivos à Lei no 2.604/55 ... definindo as atribuiç̄óes do Técnico de Enfermagem está em tramitação nas Casas do Congresso.

Recomendaçöes dos Congressos sobre o Curso Técnico de Enfermagem

R 1 - VII CBEn (1955), no 4 - $\AA$ ABEn, que estude a conveniência da criação, em lei, de outro nível de curso de enfermagem, além dos dispostos na lei 775/49.

R 2 - XVII CBEn (1965), n: 2 - a) Ao CFE que aprove para o sistema federal de ensino um currículo de curso colegial para formação de pessoal de enfermagem; b) à ABEn, que apresente, ao CFE e aos Conselhos Estaduais de Educação através das Seçð̃es Estaduais da ABEn, sugestð̄es relativas à organização desses cursos.

R 3 Da Assembleia Geral Que a Diretoria da ABEn nomeie uma Comissão Especial para o estudo dos assuntos referentes ao grau médio colegial de formação de pessoal de enfermagem.

R 4 - XIX CBEn (1967), Da Assembléia de Delegados - À $\mathrm{ABEn}$, que envie a todos os Secretários de Educação e Secretários de Saúde das Unidades da Federação, os padróes mínimos de curso colegial técnico de enfermagem bem como a lista de funçôes típicas do técnico e certas condiçōes mínimas de organização dos Colégios de Enfermagem. 
R 5 - XX CBEn (1968), n? 25 - À ABEn que manifeste ans órgãos competentes, Escolas Técnicas de Enfermagem, sua posição contra a existêr sia desses cursos.

\section{CURSO DE AUXILIAR DE ENFERMAGEM}

A idéia de preparar auxiliares de enfermagem (AE) em cursos regulares, mais rápidos e menos dispendiosos que os de enfermagem, partiu de Lais Neto dos Reys "; diretora da EE Ana Neri no período de 1938 a 1950. O primeiro grupo recebeu certificado em 1941 e desta data até 1949, quando o ensino foi oficializado pela Lei n. $775 / 49$ e Decreto no 27.426/49 formaram-se apenas $126 \mathrm{AE}$ nos cinco cursos existentes . Estes, somente a partir de 1953 é que começaram a se expandir tendo havido, desde então, um aumento progressivo anual no número de profissionais preparados nesse nível, cuja principal atividade deverá ser a de auxiliar 0 enfermeiro em suas atividades de assistência curativa. (Lei n. 775/49).

Em 1947 TABORDA 35 "m apresentou, no I Congresso Nacional de Enfermagem, um trabalho sobre a formação de auxiliares de enfermagem no qual, destacando a importância das atividades que esse grupo deveria executar, sugeria um novo curriculo para o seu preparo, uma vez que as enfermeiras já se preocupavem em ampliar as informaçōes que deviam ser dadas aos AE, tendo em vista o tipo de serviço que vinham executando nos hospitais.

Nesse mesmo trabalho a autora sugere ainda, para discussão e posterior aplicação uniforme em todo o País, que: a) o curso fosse de oito meses de duraçāo e exigisse curso primário completo como requisito para ingresso; b) fosse ministrado nos e pelos Hospitais e não nas Escolas; c) que as docentes fossem enfermeiras e não médicos; e d) que fossem determinadas as atribuiçōes dos $\mathrm{AE}$.

- Vice-Presidente da Divisão de Educação da ABEn.

- ASSOCIACÁ̃o BRASILEIRA DE ENFERMAGEM - Relatório do Centro de Levantamentos de Recursos - Necessidades de Enfermagem no Brasil. Parte IV. julho de 1959, p. 12. Mimoografia.

- Presidente da ABED. Seção do ex-Distrito Federal, de 1946 a 1950, conforme Livro de Atas n? 2. 
Em palestra pronunciada no II CBEn, 1948, Marcelino G. Candau, na época Superintendente do Serviço Especial de Saúde Pública (SESP), comentando o projeto de ensino de enfermagem sugere: 1) o aproveitamento total dos recursos e instalaçōes de que dispöem as poucas $E E$ para a formaçāo exclusiva de profissionais de mais alto padräo; 2) maior economia e facilidades para a formação de $A E$ em cursos a serem ministrados em hospitais gerais... 21

Apesar da importância do problema nenhuma recomendaçāo foi feita sobre o assunto, nesse primeiro Congresso. A ABEn, entretanto, reconhecendo que a melhoria dos serviços de saúde do País depende de altos padrōes profissionais, sempre esteve atenta para os problemas de formação desse grupo, não tendo se desviado de seu papel de oferecer orientação e rumo para a manutenção do seu nivel de ensino. Com esta finalidade vem oferecendo assessoramento não apenas a autores de projetos de criação de Curso de Auxiliar de Enfermagem (CAE) como a colegas interessadas no desenvolvimento desses cursos.

Foram muitas as recomendações feitas pelos vários CBEn sobre a formação desse elemento auxiliar ( $R \quad 1$ a 19). $O$ assunto constituiu, também, tema oficial do IV CBEn (1950).

A lei do ensino de enfermagem (Lei no 775/49) criou o curso de auxiliar de enfermagem de dezoito meses de duração e $\because$ que exigia como requisito para admissão o certificado de conclusão do curso primário ou certificado de aprovação no exame de admissão ao primeiro ano ginasial.

Apesar da Associação ter influido na elaboração do anteprojeto que deu origem a essa lei e à sua regulamentação pelo Decreto no 26.427/49, esses não sairam como as enfernneiras esperavam, no que se referia aos CAE, o que motivou a recomendação do IV . CBEn, realizado em 1950, para que a Comissão de Auxiliares de Enfermagem * estudasse a possibilidade de uma reforma quanto ao conteúdo e duração dos cursos, a fim de melhor atender a seus objetivos (R 1). - Extinta com a reforma dos Estatutos aprovada na Assembleia Geral realizada om ju-
lho de 1963 . 
COSTA 23 , em trabalho apresentado nesse Congresso, considerava longo demais um curso de mais de doze meses e critica os programas teóricos que, disse recheiados de quase todas as matérias do curso geral A seu ver, a parte mais importante do curso deveria ser a prática no campo, em períodos longos (16, dos 18 meses estabelecidos pela lei) e em todas as disciplinas consideradas básicas na Enfermagem:

O Relatório do Levantamento de Recursos e Necessidades de Enfermagem no Brasil mostrou que as disciplinas ministradas nos cursos eram insuficientes para dar aos $\mathbf{A E}$ as informaçð̋es de que necessitavam realmente, uma vez que vinham exercendo atividades mais complexas que as previstas no ensino e a maior parte das vezes sem a orientação da enfermeira. Além disso, o índice de reprovação nos CAE apresentava-se bastante elevado, em parte devido ao preparo insuficiente com que os alunos se apresentavam; para sanar esta dificuldade e ajudar os alunos a acompanharem melhor - curso, algumas escolas incluíram em seus currficulos as disciplinas português e aritmética.

A verificação desses fatos levou RESENDE ${ }^{33}$ " a sugerir em 1960 melhor preparo para o AE colocando o curso na faixa do ensino médio, à altura das $3^{a}$ e $4^{a}$ séries do 10 ciclo secundário ( $7^{\mathrm{a}} \mathrm{e} 8^{\mathrm{a}}$ séries do $1^{\circ} \mathrm{grau}$ ) na legislação atual; 0 requisito de escolaridade para ingresso deveria passar do primário para o término do 20 ano ginasial (atual 6a série do $10 \mathrm{grau}$ ). Alertava ainda a autora, com a autoridade que the davam sua cultura pessoal e sua qualidade de Presidente da ABEn, que as experiências em campo de prática deveriam ser realizadas em hospitais gerais e jamais em hospitais especializados.

De acordo com o relatório da Comissão de Documentação e Estudos da ABEn, 40\% dos alunos matriculados em 1964 tinham um nível de escolaridade superior ao primário 22 , tomava-se então- necessário que as educadoras se definissem quanto ao nível de escolaridade a ser exigido dos candidatos, uma vez que os próprios auxiliares de enfermagem consideravam insuficiente apenas o primário.

Em 1963 foi realizado em Fortaleza, Ceará, um Seminário sobre a Formaçāo de Auxiliares de Enfermagem para diretoras de escolas

- Enfermagem Medica, Cirúrgica, en Centro Cirargico, en Doencas Tranamisalvela. Pediátrica, Obstétrica, Psiquidtrica e em Saluda Pública.

- Presidente de ABEn no perfodo de 1958 a 1982. 
e cursos do nerdeste, patrocinado pela Organizaçāo Panamericana de Saúde, FISI* e Ministério da Saúde, como atividade prévia ao XV CBEn, também realizado naquela cidade. Desse seminário participou um grupo assessor do qual faziam parte cinco enfermeiras representantes da ABEn. Dos estudos realizados, 0 aperfeiçoamento do corpo docente e a revisão do currículo para os cursos de formação de AE tiveram prioridade como recomendaçōes a serem divulgadas entre as enfermeiras da região. Plano para a aplicação de ambas as recomendaçōes foi elaborado pelas participantes. $0 \mathrm{XV}$ CBEn resolveu recomendar às escolas e cursos em funcionamento no País que adotassem as recomendações dele emanadas (R 8); mais tarde, em 1965, foi realizado novo seminário, em Recife, para avaliação do programa planejado.

Pertencendo o ensino médio ao sistema estadual de ensino, é atribuição dos Conselhos Estaduais de Educação a determinação das disciplinas optativas; como esse fato poderia trazer uma diversidade de currículo nas escolas do País, a ABEn alertou as diretoras desses cursos para que estivessem preparadas para dar parecer sobre os mesmos em seus Estados, quando solicitadas.

No que se refere à regulamentação do CAE no nivel federal de ensino, a Indicação da Câmara de Ensino Primário e Médio do CFE que estabelecia o currículo mínimo do CAE foi amplamente discutida em reuniāo de diretoras de escolas e educadoras realizada em São Paulo em 1964. Uma Comissão Especial coordenada pela Presidente da ABEn foi encarregada de elaborar um Mẹmorial ao CFE sugerindo modificações na Indicação. Homologado o currículo (Portaria Ministerial n? 106/65), a ABEn constatou que suas sugestões não haviam sido acolhidas na esfera federal, mas pode: riam vir a ser nos Estados, ressalvadas as necessidades prioritárias de cada regiāo1.

Em 1967, por ocasião do XIX CBEn, foi discutida a proposta de redução do CAE para onze meses letivos, inicialmente em cursos de caráter experimental 31 . As autoras do projeto, diretora e docentes da EE Alfredo Pinto, sugeriam que esses onze meses fossem exclusivamente dedicados ao ensino das matérias de formação profissional e que fosse exigido o certificado de conclusão da $2^{a}$ série ginasial como requisito de matrícu-

- Fundo Internacional de Socorro à Infäncia. 
la. Argumentavam que os candidatos já traziam os conhecimentos gerais correspondentes às disciplinas obrigatórias das duas primeiras séries ginasiais (atuais $5^{a}$ e 6 a do 10 grau), pela Portaria no 106/65 do CFE, que consumiam um ano inteiro de estudos quando ministradas e que às disciplinas profissionais ficava reservado, portanto, apenas o outro ano do curso32. Aprovada a recomendaçāo ( $R$ 15) a ABEn encaminhou ao MEC sugestōes no sentido de reduzir o curso para onze meses $e$ aumentar a escolaridade como requisito de admissão; o Parecer 75/70 do CFE instituiu experimentalmente e disciplinou os Cursos Intensivos de AE e aumentou a exigência de escolaridade, tornando obrigatória a conclusāo do 10 ciclo ginasial, como requisito de admissão.

A inovação parece ter sido bem aceita pelas enfermeiraseducadoras, convencidas da comprovada necessidade de formação de pessoal de enfermagem a curto prażo.

Em 1969 foi realizado na Guanabara um Seminário para discussão do currículo dessa nova modalidade de curso, sob os auspícios do Ministério de Saúde e OPAS/OMS. Coordenou os trabalhos a enfermeira Judith Feitosa de Carvalho" que contou também com a colaboração de reprosentante da Comissão de Educação da ABEn. Deste Seminário resultou.a elaboração de um guia sobre um currículo integrado para os Cursos Intensivos de AE que constitui um documento de real valor para a implantação do novo sistema.

De acordo com a Comissão de Documentação e Estudos da ABEn o número de cursos dessa natureza passou de 5 em 1970 para 15 em 1971 (18,3\%) e $23 \mathrm{em} \mathrm{1972,} \mathrm{ou} \mathrm{seja,} 27,1 \%$ do total das 85 escolas ou cursos que enviaram informaçðes nesse último ano":

Recomendaçōes sobre o Curso de Auxiliar de Enfermagem

R 1 - IV CBEn (1950), no 5 - Que a ABEn, por intermédio

- Chofe do Servico de Enfermegern da Divisão Nacional de Organizaço Sanits - ria-mS.

- CARVAlmo, A. C. - Formagéo de pessoal de enfermagem. Relatório da Comissáo de Documentaço e Estudos - 1971/72 (No prolo). 
da Comissão de Auxiliares de Enfermagem estude, com a maior brevidade, para encaminhamento à Diretoria do Ensino Superior do Ministério da Educação e Saúde os elementos que servirão de base à remodelação da Lei $775 / 49$ e do seu Regulamento, no sentido de atender, da melhor forma, os objetivos do curso de Auxiliar de Enfermagem.

R 2 - VI CBEn (1952), n.0 4 - Às instituiçōes que mantêm Serviços de Enfermagem que procurem interessar os estabelecimentos de ensino, ou outras instituiçōes aptas para tal fim, na criação de cursos de auxiliares de enfermagem, em que seja dado relevo à especialidade deseja da.

R 3 Da Assembléia Geral - Que sejam revistos os currículos dos cursos de Auxiliar de Enfermagem pelas próprias diretoras a fim de que apresentem um programa mínimo que sirva de orientação decisiva do ensino.

R 4 - VII CBEn (1954), no 5 - À ABEn que intensifique seus esforços no sentido de que as entidades interessadas no preparo de auxiliares de enfermagem tomem suas iniciativas ponderadamente, baseadas na legislaçāo vigente.

R 5 no 17 - Às diretoras de EE que no processo de recrutamento aos cursos de auxiliares de enfermagem procurem atrair portadores de certificados de conclusão de curso secundário ou equivalente.

R 6 - VIII CBEn (1955), no 21 - Às EE e Escolas de Auxiliares de Enfermagem, que no currículo do curso de $\mathrm{AE}$ sejam incluídos estágios em ambulatórios e educação sanitária aplicada.

R 7 - XIV CBEn (1962), no 20 - Às EE, que preparem os auxiliares de enfermagem para atuar eficientemente no hospital - unidade sanitária, sob supervisão do enfermeiro.

- R 8 - XV CBEn (1963), n: 4 - As Escolas e Cursos de AE, que adotem, no que concerne aos cursos de $\mathrm{AE}$ as decisões do Seminánio de Diretoras e Professores de Escolas de Enfermagem, realizado em Fortaleza, Ceará, de 30 de junho a 15 de julho de 1963. 
R 9 - XVII CBEn (1965), no 11 - Às Escolas e Cursos de AE: a) que procurem entrosar os currículos dos Cursos de AE com as Escolas Ginasiais Técnicas ou Cursos Ginasiais locais para aproveitamento do corpo docente destas instituiçōes; b) ou que procurem elaborar convênios com as Faculdades de Filosofia para utilização dos recursos dos Colégios de Aplicação.

R 10 no 12 - Às Escolas e Cursos de AE que revisem seus currículos no sentido de incluir o ensino de Enfermagem Psiquiátrica.

R 11 no 15 - Às Escolas e Cursos de $\mathrm{AE}$, que intensifiquem a formação do auxiliar de enfermagem em maior número, aumentando sua capacidade de matrícula.

$$
\text { R } 12 \text { - }
$$
no 16 - À ABEn que solicite ao MEC que, ao serem elaborados os estudos de reforma de órgãos do MEC, seja dado ao ensino médio de enfermagem estrutura e hierarquia adequados para bem desempenhar sua funções de coordenação.

R 13 - XVIII CBEn (1966), n! 18 - À ABEn, que solicite ao MEC a criação de um órgão próprio constituído de enfermeiras, destinado ao estabelecimento das questões relacionadas com o ensino médio de enfermagem"e que tal órgão seja dependente da DESEC tendo em vista a eficiência com que tem desempenhado essas mesmas funções nas outras áreas profissionais, com a cooperação de órgãos de assessoria.

R 14 - XIX CBEn (1967), no 3 - Às Escolas de AE: a) que procurem facilitar $O$ ingresso de candidatos no curso, mantendo entrosamento com a direção dos estabelecimentos federais de onde provêm esses candi-: dátós; b) que procurem situar o currículo dos cursos dentro das necessidades prioritárias globais e regionais de saúde.

$$
\text { R } 15 \text { - }
$$
- À Comissão de Educação, da ABEn, que estude os planos experimentais da EE Alfredo Pinto e apresente sugestð̄es ao CFE, aos CEE e às Escolas de $\mathrm{AE}$, quanto ao currículo dos cursos de auxiliar de enfermagem.

- Incluia o curso Técnico de Enfermagsm iniciado em 1966. O ensino módio foi transformado em ensino de 10 e 20 graus com a Lei n? $5.692 / 71$. 
R 16 n.0 4 - Às diretoras de curso de $\mathrm{AE}$, que obtenham autorização da DESu antes de colocar na prática qualquer currículo experimental.

R 17 - Ao Ministro da Educação e Curtura, que na oportunidade de sua reforma administrativa crie um órgão adequado para a coordenação e controle do ensino médio (Técnico e de AE) para formação de pessoal de saúde.

R 18 - XX CBEn (1968), n! 1 - Às Escolas e Cursos de AE: a) que o estágio de cozinha e dietética seja correlacionado com os estágios de Enfermagem Médico-Cirúrgica e Materno Infantil; b) que dêm a importância devida ao preparo de auxiliares de enfermagem selecionando campo de estágio de cozinha e dietética que conte com nutricionista.

$$
\text { R } 19 \text { - }
$$
n. 5 - As Escolas ou Cursos de AE e Diretores de Serviços de Enfermagem de Hospitais, que promovam convênios ou instrumentos de cooperação mútua para extensão dos cursos de auxiliares de enfermagem, em hospitais, para preparo de atendentes. com consequente adaptação para auxiliares de enfermagem.

\section{CURSOS DE PÓS-GRADUAÇÃO}

A necessidade da organização de cursos que proporcionassem às enfermeiras possibilidades de complementar com novos estudos ou aprofundar os conhecimentos adquiridos no curso de graduação, foj percebida pela $A B E n$ desde $1947^{*}$. A partir desta data até 1968 foram várias as recomendações dos Congressos Brasileiros de Enfermagem nesse sentido ( $R \quad 1$ a $R$ 7).

0 desenvolvimento de habilidades e o conhecimento dos problemas dos pacientes ligados aos diversos ramos da enfermagem, objetivos prioritários na maioria das escolas, tomava grande parte do periodo de estudos, deixando pouca margem para a inclusão no currículo de disciplinas que deviam preparar as estudantes para as funçōes que iriam ser chamadas a exercer: administração de unidades ou mesmo de serviços de enfermagem,

- $R 1$ do 1 CBEn, 1947. 
ensino e supervisåo do pessoal auxiliar e docência em qualquer dos níveis de ensino. Dentre os ramos da Enfermagem, a Psiquiátrica mereceu recomendações especiais da $\mathrm{ABEn}$ dado o pequeno número de enfermeiras que procuravam fazer estudos complementares neste campo ( $R$ e 6 ).

Conscientes desta lacuna na formação das enfermeiras, algumas Seçð̄es Estaduais da ABEn e Escolas procuravem organizar e ministrar cursos de pequena duração, principalmente como parte das comemorações da Semana da Enfermagem". Estes estudos não eram, porém, suficientes Foi pensando assim que a Escola Ana Neri primeiro e alguns anos depois (1955) a Escola da Universidade do Estado da Guanabara resolveram iniciar cursos em nível de pós-graduação" para Formaçāo de Professores, e de Chefia de Enfermagem, de dois e um ano de duração respectivamente12,27.

Mas estes não foram considerados suficientes pelas enfermeiras, que, reunidas em 1958 no XI CBEn resolveram recomendar que a ABEn estimulasse as escolas com recursos docentes e materiais a organizarem cursos de pós-graduą̧āo, principalmente em Administraçāo e Pedagogia. ( $R$ 3).

Com grande esforço e o auxflio financeiro da Fundação W.K. Kellogg em convênio com a USP, a EEUSP conseguiu iniciar, logo em 1959, dois cursos regulares, ambos de um ano acadêmico de duração: Pedagogia e Didática aplicada à Enfermagem e Administraçāo aplicada à Enfermagem, para enfermeiras-docentes e enfermeiras de serviços hospitalares. Alguns anos depois, em 1963, foi oferecido um terceiro curso, de Administração de Ensino de Enfermagem para diretoras de escolas e cursos dos três níveis de ensino. Todos deixaram de funcionar em 1969/70; com a reforma universitária e o parecer $\mathrm{n} .077 / 69$ do CFE, novas normas foram estabelecidas exigindo outro planejamento.

Recomendaf̧ōes sobre 0 curso de pós-graduação

R 1 - VI CBEn (1952), n: 7 - Às diretoras de EE: f) que

- Oficializada pelo Decreto n: 48.202/60 - comemorada anualmente pelas Seföes da ABEn.

- O Parecer 77/69 do CFE dá nova definição a esses cursos, colocando-os nos niveis de mestrado e doutorado, a serem ministrados nas universidades. 
promova, na medida do possível o estabelecimento de cursos de pós-graduzção de especialização ou de atualização em Pedagogia, Administração e Supervisāo.

R 2 - IX CBEn (1956), no 19 - Às EE que favoreçam meios para estudos mais avançados em Enfermagem Psiquiátrica para enfermeiras que desejam dedicar-se a esse ramo da Enfermagem.

R 3 - XI CBEn (1958), no 8 - À ABEn que estimule as escolas com recursos docentes e materiais, a organizarem cursos de pós-graduação, principalmente em administração e pedagogia.

R 4 - XIII CBEn (1960), no 16 - Às EE que seja feita seleção dos candidatos aos cursos de pós-graduação e de especialização, segundo os critérios a serem sugeridos pela Comissão de Educação.

R 5 - XVII CBEn (1965), n? 8 - Às EE que considerem a oportunidade da realização de cursos de pós-graduação de pequena duração nas várias especialidades de enfermagem, para atender as necessidades regionais.

R 6 no 14 - Às EE que estudem a possibilidade de organização de cursos de pós-graduação de Enfermagem Psiquiátrica.

R 7 - XX CBEn (1968), no 6 - Às EE com Cursos de Pós-graduação que desenvolvam esforços no sentido de promover 2 intercâmbio de professores, a realizar estudos em conjunto para maior expansão de seus cursos.

\section{ATUAÇÃo EM OUTRAS ÅREAS}

A ABEn exerceu influência em várias outras atividades ligadas aos corpos docente e discente e que têm relação direta com o desenvolvimento do ensino.

Aperfeiçoamento do corpo docente - 0 problema do aperfeiçoamento do corpo docente está muito ligado ao do estabelecimento 
de cursos de pós-graduação. Antes desses serem abertos a $A B E n$ sugeria que as diretoras de escolas, que não tivessem condições de enviar suas docentes ao exterior, procurassem se utilizar de todos os meios a seu alcance para melhorar o nível intelectual e técnico profissional de suas docentes. 0 grande deficit no número de enfermeiras obrigava as escolas a se valerem de recém-diplomadas que, sem nenhuma experiência de ensino, eram levadas, muitas vezes, a ministrar aulas ou supervisionar os estágios de suas colegas de ontem. Não é de se admirar, pois, que as enfermeiras procurassem uma solução para este problema levando-o à discussão nos congressos, em nivel nacional. A própria realização anual destes sempre foi defendida como um dos meios de desenvolvimento profissional porque possibilita a troca de experiências, com seus êxitos e fracassos, tanto no campo do ensino junto às alunas, como no de servifos.

Dentre os meios recomendados pela $A B E n,(R \quad 1$ a 25) foram utilizados por várias escolas, entre outros: promoção de reuniōes periódicas do corpo docente, a organização e planejamento de estágios de pequena duração em escolas com melhores condiçōes de ensino, programas de educação em serviço de acordo com as necessidades locais, organizaç̃̃o de seminários didáticos e encontros regionais, intercâmbio de docentes das diferentes regizes do País e a participação nas atividades da ABEn como meio de desenvolvimento. A EEUSP, sempre atenta às recomendaçōes da $A B E n$, ofereceu durante alguns anos estágios de três meses de duração junto ao programa de ensino de algumas disciplinas de enfermagem para docentes de outras escolas e mesmo do exterior (Venezuela, Uruguai e Paraguai, entre outros).

Em 1956, a Comissão de Educação da ABEn, presidida por Glete de Alcântara e a Divisão de Enfermagem da Fundação Serviço Especial de Saúde Pública, dirigida por Maria Rosa S. Pinheiro, já haviam feito realizar na cidade do Rio de Janeiro o 10 Seminário de Ensino de Enfermagem ao qual compareceram docentes de quase todas as escolas de Enferma gem. A correlação do ensino teórico com o ensino de campo, a uniformidade no currículo, a integração dos aspectos psicológicos em todas as disciplinas do curso e maior assisténcia ao aluno foram alguns dos tópicos discutidos. As recomendações feitas pelo grupo de participantes serviram de guia na elaboração do currículo e na escolha de metodologia didática a ser empregada17. 
Recomendaçōes dos Congressos sobre o aperfeicoamento do corpo docente

R 1 - V CBEn (1951) no 11 - Às tiretoras de EE que: a) promovam por todos os meios adequados o aperfeiçoamento do corpo docente facilitando aos membros individuais a matrícula em cursos de posgraduação, especialização e outros de nivel superior, no País ou no estrangeiro; b) promovam o desenvolvimento do corpo docente como grupo organizzdo facultando-the meio de interaçăo indispensavel tal como o que se exemplifica com a instituiģão de reuniøes periódicas, frequentes e registradas em atas; c) estudem às necessidades individuais dos membros do corpo docente, como remuneração, bem-estar, carga de trabalho, condiçes de estudo e títulos procurando torná-los tanto quanto possivel satisfatórios e em especial dando a cada um dos membros um número de disciplinas nz̃o inferior ou superior ao recomendado pela $\mathrm{ABEn}$.

R 2 - VI CBEn (1952), no 6 - Reiterar às diretoras de EE que promovam reunióes periódicas, frequentes, do corpo docente, registradas em ata, facultando aos professores interação democrẹtica.

R 3 - IX CBEn (1956), no 8 - Às EE, que na seleçäo do pessoal docente levem em consideração tanto as qualidades morais quanto a competência técnica e didática.

R 4 no 11 - Às EE, que o ensino clinico seja assunto estudado e discutido nas reuniסes do corpo docente.

R 5 n9 12 - Que as EE proporcionem às suas instrutoras um estágio nas escolas onde $\epsilon$ feito ensino cltnico, com o fim de ampliar os seus conhecimentos didáticos.

R 6 - XI CBEn (1958), no 2 - As EE que: a) cada escola faça um estudo qualitativo do seu corpo dccente em relação aos seus objetivos; b) planeje um programa de educação em servigo baseado nas necessidades locais; e) que facilite às professoras de enfermagem frequencia a cursos que as auxiliem a exercer melhor as funģbes docentes, seja na cidade onde estiver a Escola, seja em outro local.

R 7 - XII CBEn (1959), no 2 - A ABEn que intensifique os 
esforços no sentido de obter bolsas de estudo para enfermeiras que ocupam posição de ensino ou de direção de Serviço de Enfermagem a fim de que frequentem curso de pós-graduação.

$$
\text { R } 8 \text { - }
$$
no 12 - Às diretoras de EE e de EAE que se utilizem das reuniões periódicas com o corpo docente para: a) procurar estabelecer consenso sobre a filosofia educacional da escola; b) estudar $e$ avaliar os programas, o regimento interno e as demais atividades da Escola; c) discutir a repercussão das leis, decretos e projetos de lei sobre enfermagem no currículo da Escola.

R 9 Recomendação da Assembléia Geral de 21/7/1959: que as diretoras ofereçam aos membros do corpo docente possibilidade de aperfeiçoamento, utilizando as bolsas da CAPES.

R 10 - XIII CBEn (1960), n? 7 - $\AA$ ABEn, que adote os critérios elaborados pela Comissão de Educação (tendo em vista a necessidade de critérios mínimos para a aprovação de escolas que ofereçam cursos e estágios para docentes de enfermagem).

$$
\text { R } 11 \text { - }
$$
n? 8 - $\mathbf{A}$ ABEn, que promova, através de suas Comissōes, Seminários Regionais considerando os benefícios auferidos pelos participantes do Seminário Didático sobre Integraçāo (dos aspectos sociais e de saúde no currículo) realizado em Salvador, em 1960.

$$
\text { R } 12 \text { - }
$$
Que as EE e EAE estabeleçam um plano de aperfeiçoamento do corpo docente, utilizando-se das bolsas da Coordenação do Aperfeiçoamento de Pessoal de Nível Superior (CAPES).

R 13 - XVI CBEn (1964), no 1 - A ABEn que:a) estimule as EE a prepararem seu corpo docente para a pesquisa; promova ( curso ou seminário sobre pesquisa.

R 14 no 2 - Às docentes de EE e diretoras de serviços que introduzam a pesquisa no seu campo de trabalho a fim de obterem elementos para sua avaliação.

R 15 no 3 - Às diretoras de EE e de serviços, que em seus programas de atualização de conhecimentos e 
educação em serviço dêm mais ênfase aos aspectos de relações humanas.

$$
\text { R } 16 \text { - XVII CBEn (1965), n! } 7 \text { - À Comissão de Educação }
$$
da $\mathrm{ABEn}$ que recomende às $\mathrm{EE}$ que: a) estudem a possibilidade de organizar um sistema de intercâmbio de professores-enfermeiros entre as EE das diferentes regiōes do País, a fim de possibilitar ao corpo docente a frequência a cursos de pós-graduação; b) ofereçam meios para que seus docentes frequentem cursos de pós-graduação, obtendo bolsas de estudo dos governos estaduais.

R 17 - XIX CBEn (1967), n! 2 - Às diretoras e corpo docente de $E E$ que promovam ou orientem seminários para $o$ corpo docente das escolas, com vistas a um estudo aprofundado do curriculo, principalmente das disciplinas profissionais.

R 18 n9 5 - Que a ABEn proporcione um encontro de profissionais que estão utilizando o método de instrução programada (considerando que a adoção desse método ativo de ensino por algumas EE tem demonstrado seu valor na economia de tempo, reformulação de programas e seus objetivos pelo corpo docente e maior interesse e iniciativa por parte dos alunos).

$$
\text { R } 19 \text { - }
$$
no 6 - Às EE que preparem o corpo docente para tornar eficiente o ensino do planejamento de cuidados individualizados para melhor formação dos futuros profissionais.

$$
\text { R } 20 \text { - no } 11 \text { - À CAPES que estude a }
$$
possibilidade de aumentar os recursos pira a especialização de docentes de enfermagem.

$$
\text { R } 21 \text { - }
$$
Da Assembléia de Delega. dos às diretoras de $\mathrm{EE}$, que estudem meios para a realização de encontros regionais de professores que coordenam ou ministram programas de Fundamentos de Enfermagem nos cursos de Graduação, Técnico e Auxiliar de Enfermagem*:

- Em decorréncia dessa recomendação foi realizado em 1970 pela EE de Ribeiráo Preto, sob o patrocĺnio da OPAS/OMS, o Seminário Didático sobre o Ensino de Enfermagem Médica e Cirúrgica, incluindo Fundamentos de Enfermagem. 
R 22 - XXII CBEn (1970), n9 3 - Às EE que ofereçam aos membros de seu corpo docente oportunidade para ampliar e aprofundar seus conhecimentos gerais e profissionais, relacionado às características das diversas regioes do País.

R 23 no 5 - Às. EE que estimulem a participação das docentes enfermeiras na equipe de trabalho, para que sua vivência dos problemas de serviço beneficie o planejamento das experiências práticas dos alunos.

R 24 no 7 - Às EE que estimulem a participação ativa dos membros de seu corpo docente nas atividades da ABEn.

R 25 - XXIV CBEn (1972), n. 1 - Às docentes de enfermagem: a) que se preparem para assumir atitude de liderança junto aos órgãos colegiados aos quais pertençam; b) que, nos colegiados, procurem aproveitar as oportunidades surgidas, para conseguirem que sejam considerados os objetivos da educação de enfermagem.

$$
\text { R } 26
$$
n. 4 - Às escolas e cursos dos três níveis de ensino de enfermagem: a) que obtenham a colaboração de orientador pedagógico ou de professor experiente para orientação dos novos docentes; b) que adotem um plano escrito de orientação, adaptado às necessidades individuais dos docentes $e$ aos objetivos da instituição; $c$ ) que ofereçam aos docentes recém-admitidos oportunidade para aprimoramento de seus conhecimentos e desenvolvimento de suas habilidades.

Corpo discente - 0 bem-estar dos estudantes de enfermagem e o seu cesenvolvimerito como cidadãos também nereceram a atenção da Associação. Como a lei do ensino de enfermagem (Lei no 775/49) previa residência para as estudantes, as enfermeiras reunidas no II! CBEn em 1949 preocuparam-se logo con o assunto e procuraram estabelecer os padrōes mínimos de conforto físico para residência que a $A B E n$ deveria recomendar às Escolas ( $\dot{R} 1)$.

A vida das estudantes em regime de internato e o excesso de atividades escolares provenientes da concentração de um curso de quatro 
anos ministrado em apenas três, deveria ser amenizada; a formação de um governo conjunto composto de estudantes e docentes que procurasse orientar as estudantes da resolução dos problemas surgidos, foi a solução proposta (R 2).

Além disso a $A B E n$ vem estudando, há já alguns anos, a possibilidade de introduzir em sua estrutura organizacional um órgão ao qual os estudantes possam se associar; a formação de hábitos e atitudes com relação à vida associativa é uma de suas preocupações.

Estudantes do sexo masculino não eram aceitos enı algumas escolas de enfermagem; $c$ fato mereceu recomendações dos congressos realizados em 1955, 1960 e 1968. A idéia de ser a enfermagem uma profissão eminentemente feminina ainda prevalece em certos espíritos, menos hojc que no passado ( $R$ 3, 4 e 5 ).

Reccomendaçōes dos Congressos sobre - corpo discente

R 1 - III CBEn (1949), no 5 - Que as escolas e residências sejam construídas de acordo com os requisitos essenciais ao seu bom funcionamento, a fim de salvaguardar a saúde e a vida das estudantes e de criar um ambiente em que elas possam ser preparadas para o desempenho cabal das responsabilidades que assumem ao receber o diploma de enfermcira.

R 2 - V CBEn (1951), no 11 - Às diretoras de EE que (...): g) promovam a organização dos estudantes matriculados em uma associação de alunos ou que promovam meios de vitalização das existentes ou inativas; h) que incentivem o contato dos estudantes de enfermagem com os outros estudantes universitários; i) que promovam a criação nas escolas de um órgão que reuna: membros do corpo docente e representantes do corpo discente, com a responsabilidade de promover governo conjunto para escola em todos os assuntos que não sejam de alçada exclusiva dos outros órgãos do estabelecimento, e principalmente destinada a deliberar em conjunto sobre os assuntos que dizem respeito à vida do aluno fora das áreas do ensino sistemático da escola. 
R 3 - VIII CBEn (1955), no 20 - Às EE e EAE que se interessem pela aceitaçāo de candidatos do sexo masculino em seus cursos.

R 4 - XIII CBEn (1960), no 17 - Às EE que: a) considerem, em termo de igualdade, $O$ ingresso de candidatos de ambos os sexos, nos cursos de enfermagem e de auxiliar de enfermagem; b) façam ampla divulgação da profissão entre candidatos do sexo masculino, proporcionandolhes as facilidades necessárias ao estudo da enfermagem.

R 5 - XX CBEn (1968), no 23 - $A$ ABEn que oficie às EE cujos regimentos impeçam a matrícula de rapazes, recomendando a retirada dessa proibição regimental.

Dirulgagāo do ensino de enfermagem - Não houve grande preocupação nesse sentido, nem por parte da ABEn (R 1 a 5) e nem por parte do governo. Os recursos financeiros da Associação não permitiam - e ainda não permitem - uma campanha nacional com esta finalidade e a solicitação feita ao MEC em 1958 (XI CBEn) não sensibilizou as autoridades, como também não tem sensibilizado o fato de muitas escolas lutarem com grandes dificuldades para manterem seus cursos.

As comemoraçöes da Semana da Enfermagem (12 a 20 de maio) realizadas em todas as capitais - sede de Seçōes da ABEn, têm sido um dos instrumentos de divulgação da profissão. Nessa semana são programadas palestras e entrevistas pelos meios usuais de comunicação, celebrações solenes para as quais são convidadas autoridades locais, além de visitas e excurssōes para as enfermeiras, a instituiçōes de interesse.

Outro meio de divulgação indireto são os cursos sobre assuntos de ordem geral ou profissional, também programados e realizados pelas Seções Estaduais e abertos ao público interessado.

Como divulgagão planejada foram feitos e distribuídos pela ABEn os folhetos Enfermagem - profissāo de futuro, Nāo basta vestir avental branco para ser enfermeira e Ser enfermeira ... já pensou nas oportunidades? 0 cartaz seja uma delas também fci distribuído em grande escala; - filme Enfermeinos para o Brasil não alcançou a repercussão desejada. 
Recomendaçōes dos Congressos sobre a divulgaçāo do ensino de enfermagem

R 1 - XI CBEn (1958), no 11 - Que a ABEn: a) promova uma campanha de recrutamento de candidatos para $E E$ e EAE; b) que aja como grupo de pressão para que o MEC promova uma campanha nacional de ensino de enfermagem a ser prevista no próximo orçamento da Uniāo.

R 2 - XII CBEn (1959), n? 1 - $A$ ABEn, que promova, com a colaboraräo de entidades governamentais e outras, campanha de divulgação da enfermagem visando recrutamento selecionado para as EE.

R 3 - XIII CBEn (1960), no 9 - Que a ABEn procure obter a cooperação de todas as EE e EAE para o planejamento, publicação e distribuição de folhetos sobre o ensino de enfermagem em todo o País.

R 4 n? 29 - Que seja criada a Campanha Nacional do Ensino de Enfermagem.

R 5 - XXIV CBEn (1972), no 12 a) - Às Seçōes da ABEn que promovam campanha de divulgação sobre $O$ técnico de enfermagem.

Auxilios e subvençōes para as escolas - A ABEn sempre foi pressionada pelas enfermeiras para pleitear, junto aos órgãos competentes recursos financeiros para a formação de pessoal de enfermagem em grande escala ( $R 1$ a 9). Não tem tido, porém, muito êxito. 0 preparo desse pessoal é dispendioso, principalmente no que se refere aos cursos de graduaçãopara os quais o tipo de ensino no campo, com orientação e supervisão diretas e constantes, exigc uma relação docente-aluno muito alta.

Tem sido verificada uma flutuação no número de escolas de enfermagem em funcionamento, principalmente as mantidas por entidades particulares. Os relatórios da Comissāo de Documentação e Estudos da ABEn mostram que de 1960 a 1971 foram fechadas dez escolas particulares $e$ abertas oito novas escolas: cinco particulares $e$ três oficiais.

Sabe-se, por informaçōes obtidas de suas diretoras, que 
algumas foram fechadas por absoluta falta de recursos financeiros, outras por falta de candidatos ao curso e um terceiro grupo foi transformado em escolas técnicas ou de auxiliares de enfermagem. De qualquer maneira, no segundo e terceiro casos, entra em jogo a questão financeira; um curso superion exige um corpo docente com preparo ao nivel de pós-graduação - que nem sempre pode ser realizado pela escola e nem mesmo pode ser facilitado às docentes fazerem em outras instituições. As constantes advertências feitas nos Congressos às Escolas e a própria $\mathrm{ABEn}$ para que incentivem as docentes a fazerem cursos mais avançados $e$ a procurarem obter bolsas de estudos para esse fim, tem razão de ser.

Recomendações dos Congressos sobre auxilios $e$ subvençöes para as escolas

R 1 - 11 CBEn (1948), no 4 - Que a ABEn solicite ao MES auxilio técnico e financeiro às $E E$ já existentes de modo a elevar $o$ nivel das que ainda não satisfaçam plenamente as condições necessárias e ampliar rapidamente ao máximo a capacidade das mesmas, no que diz respeito à formação de profissionais habilitadas.

R 2 - V CBEn (1951), n? 3 - Que a ABEn deve pleitear junto ao Sr. Ministro da Educação e Saúde e aos membros do Congresso Nacional a ampliação das verbas destinadas ao ensino da Enfermagem.

R 3 - VI CBEn (1952), n’o 2 - À ABEn, pleitear junto ao Sr. Ministro de Educação e Saúde e ao Congresso Nacional que se tcrnem efetivas as subvenções federais às $\mathrm{EE}$, de acordo com o expresso mandamento do artigo 23, combinado com o parágrafo 10 do artigo 16 da Lei 77 de 6 de agosto de 1949.

R 4 - VII CBEn (1954), no 1 - ̇̀ ABEn, pleitear junto ao Sr. Ministro de Educação e Cultura e ao Sr. Ministro de Saúde dotação orçamentária para ser empregada respectivamente pela Diretoria do Ensino Superior e pelo Departamento Nacional de Saúde no recrutamento e Seleção de candidatos a EE.

R 5 no 2 - $\AA$ ABEn, pleitear junto ao Sr. Ministro da Educação e Cultura e ao Congresso Nacional a concessão 
de maiores subvençð̋es às EE e EAE.

R 6 - XV CBEn (1963), no 6 - $\AA$ ABEn que: a) estimule as Seçōes do Nordeste no sentido de obterem o maior número possivel de bolsas de estudo, quer de órgãos governamentais ou particulares a fim de permitir que mais candidatos dessa região frequentem as EE e EAE locais; b) pleiteie junto à SUDENE e PETROBRÁS, a inclusão em seu plano orçamentário, de verbas destinadas às EE e EAE do Nordeste de maneira a permitir a expansão de seus programas e a concessão de bolsas de estudo a candidatos aos cursos por elas mantidos.

R 7 - XVII ĊBEn (1965), nọ 15 - À ABEn, através da Comissão do Departamento de Ensino Superior do MEC, que ajude as EE e EAE a conseguir recursos financeiros para a melhoria do ensino.

R 8 - XIX CBEn (1967) - Recomendaçāo da Assembléia de Delegados ao Sr. Ministro da Educação e Cultura, que amplie os recursos financeiros para o ensino da enfermagem de nivel superior e médio.

R 9 - XXIII CBEn (1971), no 8 - Ao MEC que faça duplicar, nos orçamentos-programa, os recursos financeiros destinados à formação de pessoal de enfermagem de grau superior e ao auxilio aos centros de formação de pessoal médio e auxiliar de enfermagem.

Padröes minimos de onganização de escolas - Convênios e filiaçōes - Padrōes mínimos para organização de EE, no rigor do termo, não chegaram a ser ainda determinados pela ABEn. Foram, no entanto, várias as orientações dadas nos Congressos sobre a localização, planta física e equipamento para construção de escolas. O III CBEn, realizado em 1949, estabeleceu o mínimo de campo clínico necessário para a formação da enfermeira e sugeria que as escolas que não òispuzessem de facilidades de campo para estágio deviam firmar convênios com instituiçōes de saúde a fim de estabelecer condiçōes adequadas para a prática dos estudantes ou procurassem utilizar dos :crursos de outras escolas por meio de filiação.

A preocupação da $\mathrm{ABEn}$ com o funcionamento de escolas de qualquer dos niveis, sem recursos adequados de pessoal e de material vem desde 1955 (VIII CBEn) quando foi feita a primeira solicitação ao 
ao MEC para que evitasse o reconhecimento de cursos em tais condiçres.

Em se tratando de profissão em que entre em jogo o bemestar ou mesmo a vida do ser humano, a qualidade do produto preparado é muito importante, daí as constantes advertências da ABEn através dos Congressos.

Recomendaçōes dos Congressos sobre os padröes minimos para organizaçāo de escolas-convênios e filiaçōes

R 1 - III CBEn (1949), n! 4 - a) Que as EE sejam localizadas nas proximidades de um grande hospital, centro médico ou centro educacional, de modo a facilitar o entrosamento do ensino teórico com a prática nos campos clínicos; b) os campos clínicos deverão ser providos dos livros mais necessários à orientação do ensino clínico e do serviço de enfermagem; c) os hospitais usados para o ensino clínico deverão possuir pelo menos uma sala de aula de que a Escola possa fazer uso.

R 2 A EE que não dispuzer de campos clínicos especiais à formação de enfermeiras deve procurar estabelecer filiação com EE que disponha de tais campos, a saber: a) Clínica e Especialidades Médicas; b) Clínica Psiquiátrica; c) Clínica e Especialidades Cirúrgicas e Salas de Operação; d) Clínica Obstétrica; e) Clínica Pediátrica; f) Clínica de Doenças Transmissíveis, incluindo doenças venéreas; g) Saúde Pública Urbana e Rural.

R 3 A EE deve conter: a) pelo menos três salas de aula: uma em anfiteatro junto ao laboratório de Técnica de Enfermagem; uma para seminários ou um auditório de uma que possa ser equipada com aparelhos de projeção; b) laboratório de Técnica de Enfermagem que seja uma replica de uma enfermeira; c) pelo menos dois laboratórios para ciências físicas e biológicas, bem equipados; d) Laboratório de $\mathrm{Nu}$ trição com capacidades para 16 estudantes e uma instrutora.

R 4 - IV CBEn (1950), n! 6 - Às EE que não disponham de recursos adequados para estágios do currículo escolar básico procurem utilizar-se dos recursos existentes em outras escolas, por meio de filiaçวิว. 
R 5 - VIII CBEn (1955), n? 1 - A ABEn que solicite à Diretoria do Ensino Superior do MEC sejam tomadas providências no sentido de evitar a autorização para funcionamento e o reconhecimento de escolas de enfermagem e de auxiliares de enfermagem que não disponharn de recursos materiais e de pessoal adequados, tanti em quantidade como em qualidade.

R 6 - XII CBEn (1959), ng 18 - Às diretoras de EF e de EAE que firmem convênios com as instituições onde ns estudantes estagiam, a fim de estabelecer condiçð̃es adequadas para a prática dos estudantes e determinada a responsabilidade da escola para com a instituição e desta para com a escola.

R 7 no 21 - Às Entidades Mantenedoras de EE e EAE que: a) dêm à escola recursos suficientes para que haja no corpo docente número adequado de enfermeiras a quem a diretora possa delegar a maior parte do ensino e supervisão dos estudantes; b) que recomendem às diretoras participação ativa no ensino, sem contudo prejudicar suas atividades administrativas.

R 8 n. 22 - Às Entidades Mantenedoras de EE e EAE que deleguem à diretoria responsabilidade pela direção da escola e autoridade correspondente para selecionar o corpo docente e pessoal administrativo, elaborar e administrar o orçamento, planejar e administrar o currículo.

R 9 n? 23 - Às Entidades Mantenedoras de EE e EAE que, quando possivel entreguem a direção da Escola a enfermeira com curso de pós-graduação.

R 10 n: 24 - Aos Serviços hospitalares e sanitários, que sejam cumpridos os convênios firmados com as escolas.

R 11 - XXIV CBEn (1972), n! 3 a) - Às Escolas e cursos dos três níveis de ensino de enfermagem que utilizßm, mediante convênio, instituiçóes de saúde para campo de prática, tanto na zona urbana como rural. 


\section{CONCLUSÃO}

O estudo procura demonstrar, por meio de uma rápida análise das resoluçōes tomadas nos Congressos, que a Associação Brasileira de Enfermagem sempre esteve atenta aos problemas ligados à formação de pessoal de enfermagem, procurando desempenhar o seu papel de entidade científica cultural $e$ alcançar os objetivos determinados pelos seus estatutos (Anexo 2).

Convencida de que a melhoria da assistência de saúde ao povo brasileiro (objetivo IX) está na dependência da qualidade do serviço prestado a este, por sua vez, do tipo de preparo recebido pelo pessoal de enfermagem, seu interesse pela formação de bons profissionais tem sido uma constante nos estudos realizados.

Da análise das funçőes da enfermagem ressalta, de início, a variedade de graus de atribuiçōes, que devem ser exercidas, logicamente, por pessoas de preparos diversos. A ABEn procura, então, colaborar na solução dos problemas de formação de enfermeiros, técnicos de enfermagem e auxiliares de enfermagem estudando e apresentando sugestões sobre planejamento e organização de currículos, duração mais adequada dos diversos cursos, disciplinas que devem integrar os currículos e aperfeiçoamento do corpo docente a fim de que possam atuar com mais eficiência no ensino em cada um desses niveis de formação.

Outros aspectos têm sido estudados, tais como: a integração do estudante de enfermagem na associação profissional, a importância de uma divulgação planejada sobre a enfermagem com o objetivo de recrutar maior número de estudantes, a necessidade de ser oferecido auxílio financeiro às escolas que contam com poucos recursos e, ainda, estudos para determinar padrões de organização de escolas.

Muito já foi realizado, mas como o progresso exige mudanças, muito mais ainda está por ser feito. Todo presente repousa nas realizaçōes do passado; qualquer programa visando ao desenvolvimento da profissão e dos profissionais fundamentar-se-á, certamente, no que foi feito ontem. 


\section{ANEXO 1}

Organizaçāo da ABEn

A ABEn é uma entidade de caráter cultural e assistencial, de personalidade jurídica, com sede no Distrito Federal.

Após sua fundação em 1926 passou pelas designaçőes de: Associação Nacional de Enfermeiras Diplomadas Brasileiras (ANEDB), Associação Brasileira de Enfermeiras Diplomadas (ABED) e por último Associação Brasileira de Enfermagem (ABEn).

Funciona através das Seçôes Estaduais localizadas nas capitais de quase todos os Estados da Federação; as Seç̋es podem subdividir-se em Distritos, criados nos municipios onde existam núcleos de, no mínimo, dez enfermeiros.

A Diretoria é o órgão administrativo e de execussão da ABEn e dela fazem parte as coordenadoras das quatro Comissóes Permanentes que integram sua estrutura atualmente: Assistência, Educação, Legislaçāo e Revista Brasileira de Enfermagem.

Seu órgão deliberativo é a Assembléia de Delegados constituida por delegados eleitos nas Assembléias Gerais das Seções; reune-se, ordinariamente, por ocasião dos Congressos anuais realizados pela $\mathrm{ABEn}$.

É filiada a duas associaçōes internacionais e uma interamericana: Conselho Internacional de Enfermagem, (ICN) desde 1929; Comite Internacional Católico de Enfermeiras e Assistentes Médico Sociais a partir de 1955; e em 1969 filiou-se à Federação Interamericana de Enfermagem.

Realiza anualmente os Congressos Brasileiros de Enfermagem, (CBEn) designados Congressos Nacionais de Enfermagem até 1955 (VIII CBEn). 


\section{ANEXO 2}

Objetivos da ABEn

I - Congregar os enfermeiros e incentivar o espírito de união e cordialidade entre os membros da classe;

II - criar condiçōes que permitam auxiliar profissionalmente cada enfermeiro, especialmente no início de sua carreira;

III - incentivar o espírito de união e cordialidade entre os enfermeiros e os representantes de profissões afins;

IV - pugnar pelo desenvolvimento da enfermagem em todos os seus ramos;

V - trabalhar pelo ensino e formação do pessoal de enfermagem e pela conservação de alto padrão de ética dos membros da classe;

VI - estudar os assuntos que interessem à profissão colaborando com as autoridades na solução de problemas a ela relacionados;

VII - cuidar do aperfeiçoamento profissional dos sócios;

VIII - orientar os enfermeiros na defesa dos interesses e direitos da classe;

IX - colaborar para a melhoria da assistência de saúde do povo brasileiro. 
CARVALHO, A.C. de - The Brazilian Nursing Association and its' contribution to the development of the teaching of nursing in Brazil. Rev. Esc. Enf. USP, 8 (1): - $\quad 1974$.

This study considers the contribution of the Brazilian Nursing Association (ABEn) in the development of the teaching of nursing in Brazil, by means of an analysis of the resolutions adapted in its annual conventions. It demonstrates that the association has always been concerned with the problems of the formation of nursing personnel and - in this area has continally fulfilled its role as a cultural-scientific entity.

\section{REFERENCIAS BIBLIOGRÅFICAS DOS CAPITULOS III, IV, V, VI e VIII}

1. AlCÂntara, G. - Relatório da Comissāo de Educaçāo. Revista Brasileira de Enfermagem, 18 (4): 415-418, out. 1965.

2. ANGE, Maria - 0 ensino da enfermagem no País em confronto com o projeto de Diretrizes e Bases da Educação Nacional. Revista Brasileira de Enfermagem, 12 (3): 210-222, set. 1959.

3. ASSOCIAÇÃO BRASILEIRA DE ENFERMAGEM - Anteprojeto de currículo mínimo de Enfermagem. Revista Brasileira de Enfermagem, 23 (3, 4, 5 e 6): 42-44, jul. - dez., 1970.

4. - Comissāo de Educação. Relatório das atividades. Revista Brasileira de Enfermagem, 24 (5): 234-236, jul. - set., 1971.

5. - Curso de Enfer. magem. Relatório da Comissão de Peritos. Revista Brasileira de Enfermagem, 16 (1): 6-14, fev., 1963.

6. - XXII Congresso Brasileiro de Enfermagem. Recomendações. Revista Brasileira de Enfermagem, 23 (3, 4, 5 e 6): 35-41, jul. - dez., 1970.

7. - Editorial. Anais de Enfermagem, 16 (22): 3, jan. - mar., 1947.

8. - Editorial. Añais 9. de Enfermagem. 1(1):55-56, abr., 1948. de Enfermagem, 2 (3):99-100, jul., 1949. 
10. nitária. Anais de Enfermagem, 2(1): 3-4, jan., 1949.

11. - Exposição de motivos da Comissão de Peritos em Enfermagem da ABEn. Revista Brasileira de Enfermagem, 16 (1): 14-20, fev., 1963.

12. - Notícias -

Cursos de pós-graduação e especialização. Revista Brasileira de Enfermagem, 2 (4): 303, dez., 1956.

13. ASSOCIAÇÃO BRASILEIRA DE ENFERMEIRAS DIPLOMADAS I Congresso Nacional de Enfermagem. Anais de Enfermagem, 15 (21): 10, out. - dez., 1946.

14. - Relatório da Comissão de Legislação. Revista Brasileira de Enfermagem, 18 (4): 432-442, out. 1965.

15. - Resoluçóes do I Congresso Na: cional de Enfermagem. Anais de Enfermagem, 16 (22): 68, jan. mar., 1947.

16. - Resolugroes do IV Congresso Nacional de Enfermagem. Anais de Enfermagem, 4 (1): 28-31, jan., 1951.

17. - Seminário de Ensino de Enfermagem. Revista Brasileira de Enfermagem, 9 (3): 138-147, set., 1956.

18. - Substitutivo do Parecer 271. Revista Brasileira de Enfermagem, 16 (1): 16-20, fev., 1963. 19. BRASIL. MINISTÉRIO DA EDUCAÇÃO - Parecer no 271 do Conselho Federal da Educação. Revista Brasileira de Enfermagem, 16 (1): 46, fev., 1963.

20. - Portaria no 159 de 14 de junho de 1965. Fixa sob novos critérios a duração dos cursos superiores (D.O. de 23 de junho de 1965).

21. CANDAU, M.G. - 0 problema da Enfermagem no Brasil. Anais de Enfermagem, 1 (4): 159-165, out., 1948.

22. CARVAlHo, Amalia C. - Relatório da Comissão de Documentação e estudos. Revista Brasileira de Enfermagem, 17 (5): 383-391, out., 1964.

23. COSTA, Aurora A. - Programa para o curso de Auxiliar de Enfermagem. Anais de Enfermagem, 4 (1): 135-139, jan. 1951.

24. DOURADO; H.G. - Editorial. Revista Brasileira de Enfermagem, 
10 (2): 105-106, jun., 1957.

25. - Funcionamento, duraçāo e currículo do curso de auxiliar de enfermagem. Anais de Enfermazem, $4(1)$ : 128-135, jan., 1951.

26. DOURADO, H.G. - Técnico de Enfermagem - Curso Colegial de três anos. Revista Brasileira de Enfermagem, 19 (2-3): 61-62, abr. - jun., 1966.

27. PAIXÃO, W. - Importância dos cursos de pós-graduação na profissão de enfermagem. Revista Brasileira de Enfermagem, 11 (2): $122-$ 130, jun., 1959.

28. PINHEIRO, M.R. - A inclusāo de Pedagogia, Supervisão e Administração no currículo das Escolas de Enfermagem. Anais de Enfermagem, S (4): 319-333, out., 1952.

29.

- Programa para cursos de enfermeira-chefe. Anais de Enfermagem, 16 (22): 36-40, jan., mar., 1947.

30. - Relatório da Presidente. Revista Brasileire de Enfernnagem, 9 (4): 201-210, dez., 1956.

31. PONTES, C., AlVARENGA, A. e RIVERA, S.F. - Formação do pessoal de enfermagem. Tendências atuais. Revista Biusileira de Enfermagem, 22 $(1,2): 7-18$, jan. - jun., 1970.

32. PONTES, C. \& col. - Currículo experimental para o curso de Auxiliar de Enfermagem da Escola de Enfermagem Alfredo Pinto. Revista Brasileira de Enfermagem, 21 (5): 478-489, out., 1968.

33. RESENDE, M.A. - Ensino de Enjermagem. Revista Brasileira de Enfermagem, 14 (2): 110-158, abr., 1961.

34. SOUZA, Nicea - Como vi o $X$ Congresso Internacional de Enfermagem. Anais de Enfermagem. I (1): 60-64, mar., 1954.

35. TABORDA, Rosaly $R$. Formação de auxiliares de enfermagem. Anais de Enfermagem, 16 (22): 48-49, jan. - mar., 1947. 